Portland State University

PDXScholar

9-19-1997

\title{
Comparison of Cardiovascular Disease Risk In Japanese Natives and Japanese Americans
}

Mayumi Takeda

Portland State University

Follow this and additional works at: https://pdxscholar.library.pdx.edu/open_access_etds

Part of the Cardiovascular System Commons, and the Community Health Commons Let us know how access to this document benefits you.

Recommended Citation

Takeda, Mayumi, "Comparison of Cardiovascular Disease Risk In Japanese Natives and Japanese Americans" (1997). Dissertations and Theses. Paper 5371.

https://doi.org/10.15760/etd.7244

This Thesis is brought to you for free and open access. It has been accepted for inclusion in Dissertations and Theses by an authorized administrator of PDXScholar. Please contact us if we can make this document more accessible: pdxscholar@pdx.edu. 


\section{THESIS APPROVAL}

The abstract and thesis of Mayumi Takeda for the Master of Science in Health

Education were presented June 30,1997, and accepted by the thesis committee and the department.

COMMITTEE APPROVALS:

Gary R. Brodowicz, Chair

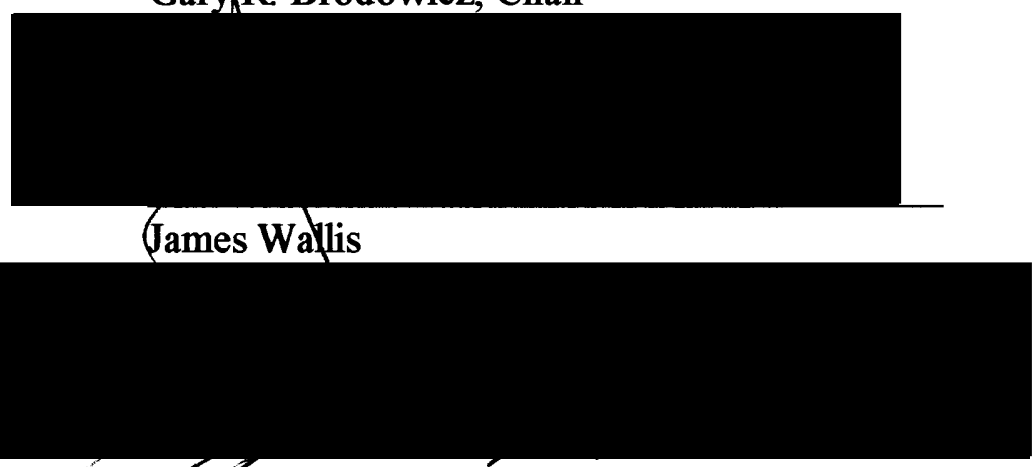

Lester J. Newman

Representative of the Office of Graduate Studies

DEPARTMENT APPROVAL:

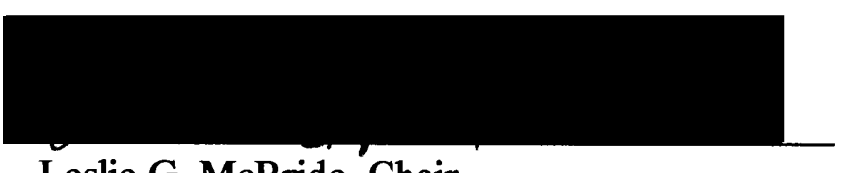

Leslie G. McBride, Chair

School of Community Health
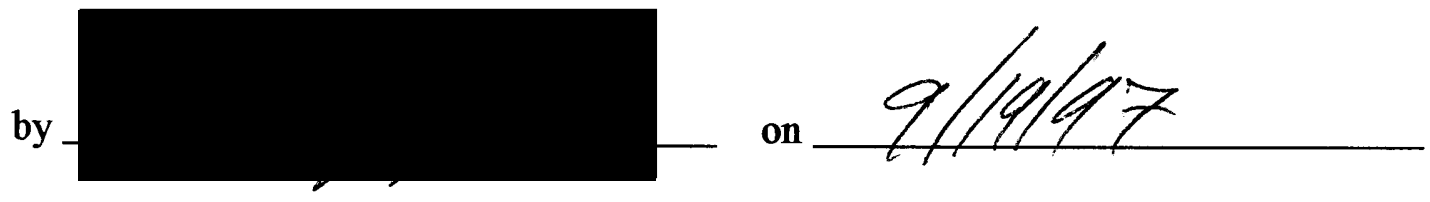


\begin{abstract}
An abstract of the thesis of Mayumi Takeda for the Master of Science in Health Education presented June 30, 1997.
\end{abstract}

Title: Comparison of Cardiovascular Disease Risk in Japanese Natives and Japanese Amerians.

This research examined potential differences in cardiovascular disease risk (CVR) in two groups: Japanese Natives living in Saga, Japan and Japanese Americans living in or near Portland, Oregon. It explored data gathered in an effort to build a theoretical framework for future studies. Environmental, nutritional, and lifestyle differences were also examined to compare the health status of Japanese residents in the two countries. The history of Japan from World War II to present, and the history of Japanese Americans both first and second generation, are discussed in the literature review.

Accelerated plethysmography (APG) is a technique which presumably allows the early detection of circulatory insufficiency. It is designed to measure the pattern of blood flow in the index finger. This method is used to evaluate the peripheral circulation by classifying the APG waveforms into seven major patterns. Based on this classification, the APG might evaluate health status regarding cardiovascular disease risk (CVR). This investigation also compared the data gathered by the technique of the APG with cardiovascular disease risk questionnaires in order to examine the efficacy of using the APG to evaluate cardiovascular disease risk. 
The comparison of health status in the two groups revealed several differences: Japanese American males are heavier than Japanese Native males and both Japanese American males and females take more prescription medications, and have better exercise habits than Japanese Natives. These differences could account for the higher APG-index in Japanese Americans. However, this research found that despite these differences, there was no correlation between the APG-indices and CVR factors. Further research is needed to determine whether the APG-index can be useful in the study of cardiovascular disease risk. 
COMPARISON OF CARDIOVASCULAR DISEASE RISK

IN

JAPANESE NATIVES

AND

JAPANESE AMERICANS

by

MAYUMI TAKEDA

A thesis submitted in partial fulfillment of the requirements for the degree of

MASTER OF SCIENCE
in
HEALTH EDUCATION

Portland State University

1997 


\section{DEDICATION}

To my former thesis committee member, Milan Svoboda, Ph.D., who passed away in March, 1997, from pancreatic cancer for his love and teaching.

To my father, Taisuke Takeda, who passed away in December, 1994, from colon cancer for his love and memory.

To my American little brother, Stephen D. Wagner, who passed away in September, 1991, by a tragic accident for his love and faith. 


\section{ACKNOWLEDGMENTS}

The writer wishes to express her deep appreciation to Portland State University for making it possible to do this study. Everlasting gratitude is due to Dr. Gary Brodowicz for his patience, scholarly advice and encouragement throughout preparation and completion of this thesis. Especially, thank you for all of the red pens you used, and for your time, energy, and wisdom.

My thesis committee - James Wallis, M.S. from whom I have learned so much about the athletic training discipline and Lester J. Newman, Ph.D. who fostered my interest in Biology as an undergraduate, for your valuable amendments.

Frosti McClurken-Talley, my best friend through my entire school life in the U.S., for her caring, assistance, and generosity.

I owe special thanks to my parents for their continued support and encouragement throughout this undertaking. 
AKNOWLEDGMENTS $\ldots \ldots \ldots \ldots \ldots \ldots \ldots \ldots \ldots \ldots$ iii

LIST OF TABLES $\ldots \ldots \ldots \ldots \ldots \ldots \ldots \ldots \ldots \ldots \ldots \ldots \ldots \ldots \ldots$

LIST OF FIGURES $\ldots \ldots \ldots \ldots \ldots \ldots \ldots \ldots \ldots \ldots \ldots \ldots \ldots \ldots \ldots$ vii

CHAPTER

I. INTRODUCTION $\ldots \ldots \ldots \ldots \ldots \ldots \ldots \ldots \ldots \ldots$

Statement of the Problem .................. 3

Hypothesis $\ldots \ldots \ldots \ldots \ldots \ldots \ldots \ldots \ldots$

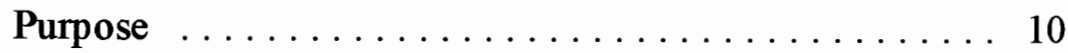

Significance of the Study . . . . . . . . . . . . . . . 10

Limitations and Assumptions . . . . . . . . . . . 11

II. REVIEW OF LITERATURE $\ldots \ldots \ldots \ldots \ldots \ldots \ldots \ldots \ldots$

Comparison of Population Densities . . . . . . . . . . . . 13

Japanese Americans $\ldots \ldots \ldots \ldots \ldots \ldots \ldots \ldots$

Japanese Natives . . . . . . . . . . . . . . . 18

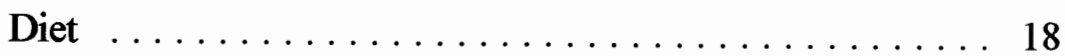

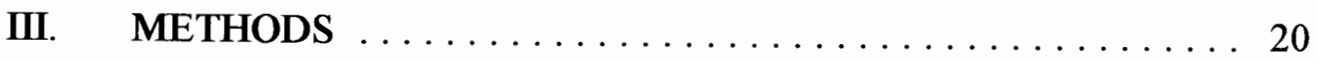

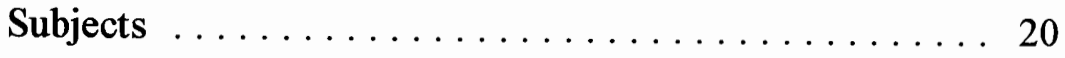

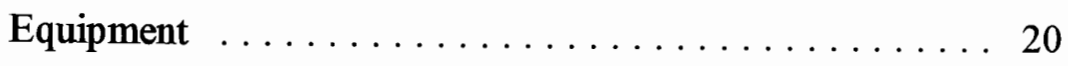

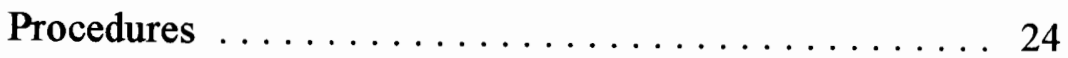


Data Analysis ................... 25

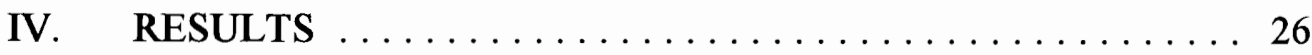

Descriptive Characteristics $\ldots \ldots \ldots \ldots \ldots \ldots 26$

Cardiovascular Disease Risk $\ldots \ldots \ldots \ldots \ldots \ldots 28$

Exercise Habits $\ldots \ldots \ldots \ldots \ldots \ldots \ldots \ldots \ldots \ldots$

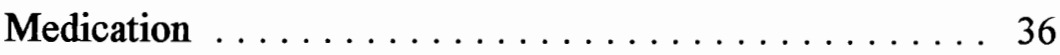

Smoking \& Drinking Habits $\ldots \ldots \ldots \ldots \ldots \ldots \ldots$

V. DISCUSSION $\ldots \ldots \ldots \ldots \ldots \ldots \ldots \ldots \ldots \ldots \ldots \ldots \ldots$

Cardiovascular Disease Risk Variables $\ldots \ldots \ldots \ldots \ldots 41$

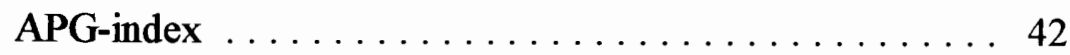

Health Care System ................... 43

Dietary Habit $\ldots \ldots \ldots \ldots \ldots \ldots \ldots \ldots \ldots \ldots$

Lifestyle $\ldots \ldots \ldots \ldots \ldots \ldots \ldots \ldots \ldots \ldots \ldots$

VI. SUMMARY, CONCLUSION, AND RECOMMENDATIONS .. 46

Summary $\ldots \ldots \ldots \ldots \ldots \ldots \ldots \ldots \ldots \ldots \ldots$

Conclusion $\ldots \ldots \ldots \ldots \ldots \ldots \ldots \ldots \ldots \ldots \ldots$

Recommendations .................. 47

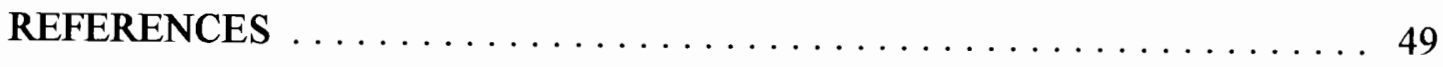

APPENDICES
A. A Personal File $\ldots \ldots \ldots \ldots \ldots \ldots \ldots \ldots \ldots \ldots \ldots \ldots$
B. Questionnaire $\ldots \ldots \ldots \ldots \ldots \ldots \ldots \ldots \ldots \ldots \ldots \ldots$

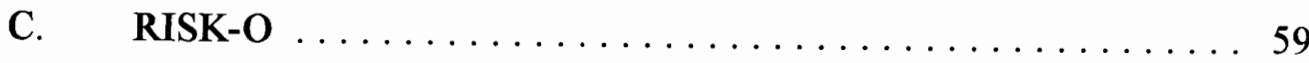




\section{LIST OF TABLES}

TABLES

I. LEADING CAUSES OF DEATH IN DIFFERENT AGE GROUPS

IN JAPAN $1995 \ldots \ldots \ldots \ldots \ldots \ldots \ldots \ldots$

II. COMPARISON OF POPULATION DENSTIY . . . . . . . . . 14

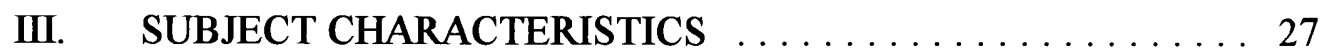

IV. CARDIOVASCULAR DISEASE RISK VARIABLES . . . . . 29

V. CORRELATION MATRIX (JA) MALE \& FEMALE . . . . . . 32

VI. CORRELATION MATRIX (JN) MALE \& FEMALE . . . . . . 33

VII. OBESITY CLASSIFICATION BASED ON BMI . . . . . . . 34

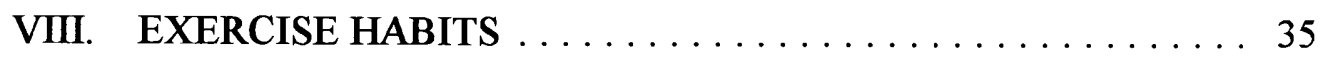

IX. MEDICATION ................... 37

X. SMOKING HABITS ................... 39

XI. DRINKING HABITS .................. 40 


\section{LIST OF FIGURES}

\section{FIGURE}

1. Components (a-e) of accelerated plethysmogram (APG). . . . . 23

2. Typical patterns (A-G) of accelerated plethysmogram (APG). . . 23 


\section{CHAPTER I}

\section{INTRODUCTION}

Japan is a small country which is surrounded by seas. More than one hundred twenty five million people share the land (See Table II, p.18). The population density per square mile is 860.5 in Japan, while it is 32.1 in Oregon (See Table II, p.18). Urbanization in Japan has been changing not only the natural environment, but also the patterns of human life. Presently, the Japanese are surrounded by contaminated air, water, and soil, which must ultimately influence their health (Swinbanks, 1995).

A Japanese word "karoshi" refers to the phenomenon of sudden death from prolonged, intensive overwork. The cause of death from "karoshi" is usually diagnosed medically as a stroke (Hamajima, 1992). Adults in their thirties and forties (middle-aged workers) are the most common victims because they work long, unrelenting hours (Uehata, 1991). Japan's post-war economic success is largely attributable to the ethic of workaholism (Hayashi, Kobayshi, Yamaoka, \& Yano, 1991).

On the other hand, workers in the U.S. have more living space with more regular work hours including more days off.

"On average, American houses are 1.6 times the size of Japan's. On a per capita basis they are 1.8 times larger and also average annual working hours has been declining in Japan, but is still about $10 \%$ higher than that of the U.S. Japan has an average of ten fewer paid vacation days than the U.S." (JETRO, 1991).

Most American elderly people do not live with their childern. After a spouse's death, it is common for a person to live alone or in a retirement home. 
"The percentage of senior citizens living alone in Japan is $4.0 \%$, while it is in the U.S. is $9.5 \%$ and also, the ratio of the number of people aged 65 and over to the number of beds in nursing homes for the aged is higher in Japan than in the U.S. The ratio is 57.9 in Japan and 17.1 in the U.S." (JETRO, 1991).

This independent lifestyle in the U.S. might make them more active and healthy.

However, increased fatty food availability has made people more prone to obesity in the U.S. According to a nutrition text book, "one group of scientists studied 155 obese men who were eating a typical American diet - about 15 percent of total calories from protein, 38 percent from carbohydrate, 41 percent from fat, and 6 percent from alcohol. Their total average food-energy intakes $(2,570$ calories per day) fell short of current recommendations $(2,900$ calories per day). The researcher found that the more fat a man ate, the fatter was his body and, conversely, that the more carbohydrate a man took in, the lower his body fat" (Hamilton, Whitney, \& Sizer, 1991, p.360).

Since the early 1900 's, the number one killer in the United states has been cardiovascular disease in every year but one (1918) (1997 Heart and Stroke, American Heart Association). Deaths do not tell the whole story, but the problem of the obesity in the U.S. seems to be similar to the phenomenon of Japanese environmental pollution because both present increased risk and are very difficult to ameliorate.

This research is focused on assessing the living conditions and the quality of life of Japanese Americans living in or near Portland, Oregon and Natives living in Saga, Japan, over forty years of age, and examining cardiovascular disease risk (CVR). CVR may be evaluated directly through hypertension, diabetes, cholesterol, smoking, inactivity, and heredity. Also, there are other indirect factors, such as population 
density, pollution problems, food availability, eating habits, working time or social pressure, and whether the person smokes or is exposed to passive smoke.

\section{STATEMENT OF THE PROBLEM}

Surprisingly, many elderly Japanese Americans still maintain the traditional Japanese lifestyle and customs. This includes diet, way of life, collecting Japanese furniture, dishes and utensils, clothing, and maintaining familiar traditions. Japanese Americans serve their guests green tea in a Japanese cup. At dinner, traditional Japanese food, such as plain rice, miso soup, fish and vegetables is served in a Japanese rice bowl with chopsticks. Also, all family members sit at a traditional low table, called a "kotatsu,"and enjoy watching television during the winter season. The majority of people in this age group have no property and few relatives left in Japan and they feel they cannot go back. Therefore, their image of Japan is amazingly different from that of modern young Japanese students. Elderly Japanese Americans recollect their childhood, parents, and hometowns.

Forty years ago, when they arrived in the U.S., they could not openly adhere to Japanese cultural traditions because Americans did not appreciate the Japanese. In fact, Japanese Americans often experienced hostility from other Americans. They dared not speak Japanese or teach Japanese to their children. They desperately tried to be assimilated into the dominant American culture. Now it has been more than fifty years since the end of World War II, and they can speak up and be proud of their Japanese heritage because Japan has become an economic world leader. 
In recent years, a sense of cultural pride has emerged and the Japanese Americans practice the customs of their youth and congregate in Japanese churches and other organizations to speak their language and socialize with other Japanese Americans. In Portland, for example, elderly Japanese Americans especially enjoy the connections they make with younger people who were raised in Japan with a knowledge of Japanese traditions. Although they have lost their own connections to Japan, they feel they have regained them through such associations and companionship.

In spite of Japanese Americans' sentimentality about their country, if they were to go back, they would be very surprised and perhaps disappointed. Things in Japan have changed dramatically. They would probably agree that their living conditions in the U.S. are much better than those in Japan. The extremely fast-paced life style in Japan would likely make many Japanese Americans very unhappy. They would notice and experience immediately that there is serious air and noise pollution. Prices are extremely high and space must be shared by many people. Since many insensitive smokers exist in public places, such as restaurants, lounges, and offices, second hand smoke in close quarters is very common. 
TABLE I

LEADING CAUSES OF DEATH IN DIFFERENT AGE GROUPS IN JAPAN ‘95

\begin{tabular}{|c|c|c|c|c|c|}
\hline Age & $\# 1$ & $\# 2$ & $\# 3$ & $\# 4$ & $\# 5$ \\
\hline $40-44$ & Cancer $(7,845)$ & $\begin{array}{l}\text { Heart disease } \\
(2,472)\end{array}$ & $\begin{array}{l}\text { Cerebrovascular } \\
\text { disease }(2,313)\end{array}$ & $\begin{array}{l}\text { Accidents } \\
(2,071)\end{array}$ & Suicide $(1,558)$ \\
\hline $45-49$ & Cancer $(17,003)$ & $\begin{array}{l}\text { Cerebrovascular } \\
\text { disease }(4,864)\end{array}$ & Heart disease $(4,856)$ & $\begin{array}{l}\text { Accidents } \\
(3,027)\end{array}$ & Suicide $(2,227)$ \\
\hline $50-54$ & Cancer $(25,013)$ & $\begin{array}{l}\text { Cerebrovascular } \\
\text { disease }(6,895)\end{array}$ & Heart disease $(6,417)$ & $\begin{array}{l}\text { Accidents } \\
(3,558)\end{array}$ & Suicide $(2,539)$ \\
\hline $55-59$ & Cancer $(36,074)$ & $\begin{array}{l}\text { Heart disease } \\
(9,657)\end{array}$ & $\begin{array}{l}\text { Cerebrovascular } \\
\text { disease }(9,328)\end{array}$ & $\begin{array}{l}\text { Accidents } \\
(3,970)\end{array}$ & Suicide $(2,228)$ \\
\hline $60-64$ & Cancer $(57,755)$ & $\begin{array}{l}\text { Heart disease } \\
(15,336)\end{array}$ & $\begin{array}{l}\text { Cerebrovascular } \\
\text { disease }(14,649)\end{array}$ & $\begin{array}{l}\text { Accidents } \\
(4,763)\end{array}$ & $\begin{array}{l}\text { Liver disease } \\
(2,582)\end{array}$ \\
\hline $65-69$ & Cancer $(73,084)$ & $\begin{array}{l}\text { Heart disease } \\
(21,583)\end{array}$ & $\begin{array}{l}\text { Cerebrovascular } \\
\text { disease }(20,854)\end{array}$ & $\begin{array}{l}\text { Accidents } \\
(4,949)\end{array}$ & $\begin{array}{l}\text { Pneumonial } \\
\text { bronchitis } \\
(4,699)\end{array}$ \\
\hline $70-74$ & Cancer $(70,697)$ & $\begin{array}{l}\text { Cerebrovascular } \\
\text { disease }(28,704)\end{array}$ & $\begin{array}{l}\text { Heart disease } \\
(28,117)\end{array}$ & $\begin{array}{l}\text { Pneumonial } \\
\text { bronchitis } \\
(7,907)\end{array}$ & $\begin{array}{l}\text { Accidents } \\
(5,493)\end{array}$ \\
\hline $75-79$ & Cancer $(67,459)$ & $\begin{array}{l}\text { Cerebrovascular } \\
\text { disease }(41,906)\end{array}$ & $\begin{array}{l}\text { Heart disease } \\
(38,559)\end{array}$ & $\begin{array}{l}\text { Pneumonial } \\
\text { bronchitis } \\
(13,701)\end{array}$ & $\begin{array}{l}\text { Accidents } \\
(5,828)\end{array}$ \\
\hline $79-84$ & Cancer $(62,962)$ & $\begin{array}{l}\text { Cerebrovascular } \\
\text { disease }(60,758)\end{array}$ & $\begin{array}{l}\text { Heart disease } \\
(52,811)\end{array}$ & $\begin{array}{l}\text { Pneumonial } \\
\text { bronchitis } \\
(21,842)\end{array}$ & $\begin{array}{l}\text { Accidents } \\
(5,975)\end{array}$ \\
\hline $85-89$ & $\begin{array}{l}\text { Cerebrovascular } \\
\text { disease }(54,851)\end{array}$ & $\begin{array}{l}\text { Heart disease } \\
(46,890)\end{array}$ & Cancer $(37,526)$ & $\begin{array}{l}\text { Pneumonial } \\
\text { bronchitis } \\
(21,864)\end{array}$ & Senility $(6,234)$ \\
\hline $90-$ & $\begin{array}{l}\text { Cerebrovascular } \\
\text { disease }(36,345)\end{array}$ & $\begin{array}{l}\text { Heart disease } \\
(33,011)\end{array}$ & $\begin{array}{l}\text { Pneumonia/bronchitis } \\
(16,835)\end{array}$ & $\begin{array}{l}\text { Cancer } \\
(15,339)\end{array}$ & Senility $(10,986)$ \\
\hline $\begin{array}{l}\text { Total death } \\
\text { in } 1995 \text {. } \\
(922,139)\end{array}$ & $\begin{array}{l}\text { Cancer } \\
(263,022)\end{array}$ & $\begin{array}{l}\text { Cerebrovascular } \\
\text { disease }(146,552)\end{array}$ & $\begin{array}{l}\text { Heart disease } \\
(139,206)\end{array}$ & $\begin{array}{l}\text { Pneumonial } \\
\text { bronchitis } \\
(79,629)\end{array}$ & $\begin{array}{l}\text { Accidents } \\
(45,323)\end{array}$ \\
\hline
\end{tabular}

Department of Welfare. (1996). The Movement of National Health. Tokyo, Japan: Health and Welfare Statistics Association. $\underline{43}$ (9), 30-33. 
Generally speaking, the Japanese live in high population density areas with a great deal of social pressure. Living expenses, including food and housing, are much higher than in the U.S. They have less vacation time, and usually work even after retiring by finding a new job or continuing the same job (Hinrichs, Roche, \& Sirianni, 1991; Bosch, Dawkings, \& Michon, 1994). They live close together in small living spaces, so air, water, noise, and soil pollution are high. Pollution from cigarettes, cigarette ashes, and cigarette stubs are one of the causes of air, water, and soil pollution. Recently, the problems of environmental pollution have been recognized as being more diverse and complex than was previously thought. Among them are increasing air contamination by nitrogen oxide, industrial waste and its disposal, groundwater contamination and soil pollution by agricultural chemicals and other chemical substances.

"In fiscal year 1991, the total budget for environmental conservation was 1,451 billion yen (about $\$ 14$ billion U.S. dollars), or $8.3 \%$ more than in the previous fiscal year. Of the total budget, expenditure for measures against pollution constituted $88.6 \%$, and expenditure for measures to conserve natural environment 11.4\%" (Statistics Bureau, 1993).

Japan is struggling to deal with these pollution problems, and efforts are being made to substitute cleaner energy sources for petroleum and to install and improve pollution control facilities.

Furthermore, since land prices are very high, people in Japan rarely own their houses.

"Land prices, especially those in residential areas, are considerably higher in Japan than in the U.S. Prices in rural areas in Japan are even more expensive 
than preferred residential areas in Los Angeles. Also, the percentage of single-family detached dwellings in the total number of houses has been declining due to high land prices and the high costs of the houses themselves" (JETRO, 1991).

Consequently, most people live in high-rise apartments. Since most people cannot buy a house, they settle for a new car instead. All these cars contribute to the pollution, space, and traffic problems. People living every day under these conditions experience an inordinate amount of stress. Due to the competitive and high stress nature of the Japanese society, smoking and drinking are very common.

"Japanese spend large amounts on books and package tours, while Americans spend more on radios, television sets, musical instruments, leisure vehicles (including boats and private aircraft), and sports equipment" (JETRO, 1991).

In addition, the Japanese rely heavily on taking ergogenic remedies to "boost their vitality" and help relieve stress, and they spend a lot of money buying them. For example, ordinary people buy an ergogenic drink (per drink $\$ 2-\$ 50)$ as easily as American purchase a cup of coffee. Moreover, Japanese are very interested in trying natural medicines made of herbs and animals for their chronic dieseases. Japanese Natives should realize now that effective tools for decreasing stress and the consequent attainment of longevity are actually acquired by the manipulation of diet, an increase in physical activity, management of stress, and a decrease in smoking and drinking. The environmental choices might be even more carefully considered by the Japanese. Like many Japanese emigrants who left to seek their fortunes in the new world, current teenagers in Japan may choose to live outside of Japan in the future. 
'Many Japanese workers feel more loyal to their companies than American workers. Working oneself to death and suicide is not uncommon. Unlike their elders, may young Japanese workers want to spend less time working and more pursuing leisure activities" (Brown, Lubove, \& Kwalwasser, 1994).

Modern elderly Japanese Natives do not have a choice regarding their living place, but they have good dietary habits. They prefer low cholesterol foods such as tofu, sashimi (a piece of very fresh raw fish), and plain rice, but environmentally, there are many negative factors related to cardiovascular disease in Japan. Even though they drink whole milk (if they drink milk at all), dairy products are expensive, so they do not consume nearly as much as elderly Japanese Americans.

"Almost all kinds of food are more expensive in Japan than in the U.S. Especially, Japan produces and consumes far less beef than the U.S. Imports account for $40 \%$ of the beef consumed in Japan. Therefore, the per capita daily intake of nutrients in Japan is considerably lower than of the U.S." (JETRO, 1991).

Fortunately, this prevents elderly Japanese Natives from developing high cholesterol. In addition, elderly Japanese Natives do not consume much processed food. Their food is usually prepared from fresh vegetables and fish, so they spend a lot of time cooking. This limits exposure to harmful preservatives, which is another positive factor for elderly Japanese Natives.

On the other hand, there are plentiful meats, dairy products, fruits and vegetables, and beans and grains in the U.S., so elderly Japanese Americans can get these foods at cheaper prices. The average American diet is relatively high in fat when compared with the diet of the average Japanese Natives. However, most elderly Japanese Americans continue to cook with the Japanese cooking style. In addition to such a 
low cholesterol diet, they are surrounded by plenty of fresh air, green grass, parks, and spacious living quarters. Furthermore, elderly Japanese Americans have more days off and retire early and defintely so that they can get away from social pressures sooner (Mirkin, 1987; Hinrichs, Roche, \& Sirianni, 1991). Larger living spaces per person with easy access to fresh air and green open space seems to be the preferred choice.

The typically lower-fat, fresh food diet of the Japanese combined with such working conditions as an eight-hour-day, adequate days off, and early retirement as well as adequate personal space are conducive to a lower cardiovascular disease risk. Likewise, a poor diet, high in fat, and high-stress living (e.g, overwork and inadequate personal space) are conducive to a higher CVR. These factors lead to the hypothesis that there may be a difference in cardiovascular disease risk between Japanese Natives and Japanese Americans.

\section{HYPOTHESIS}

Since this was an exploratory descriptive study, the hypothesis tested were nondirectional (i.e., two-tailed). The null and alternate hypotheses were as follows:

$$
\begin{aligned}
& \mathrm{H}_{0}: \mathrm{CVR}_{\mathrm{JN}}=\mathrm{CVR}_{\mathrm{JA}} \\
& \mathrm{H}_{1}: \mathrm{CVR}_{\mathrm{JN}} \neq \mathrm{CVR}_{\mathrm{IA}}
\end{aligned}
$$

where $\mathrm{CVR}_{\mathrm{JN}}$ denotes mean cardiovascular risk of Japanese Natives and $\mathrm{CVR}_{\mathrm{IA}}$ denotes mean cardiovascular risk of Japanese Americans. Statistical significance was determined using an alpha level of 0.05 . Since there is no extant research on Japanese 
American cardiovascular risk, the hypothesis was focused on finding differences between these two populations. The research hypothesis was that there exists a statistically significant difference between the Japanese Native and Japanese American populations in terms of cardiovascular risk.

\section{PURPOSE}

The purpose of this study was to compare the cardiovascular disease risk for Japanese individuals living in the United States with those living in Japan, and to determine whether a significant difference exists. This investigation also compared the data gathered by the technique of APG with cardiovascular disease risk questionnaires in order to examine the efficacy of using the APG to evaluate cardiovascular disease risk.

\section{SIGNIFICANCE OF THE STUDY}

If differences in cardiovascular disease risk could be identified, what does it mean for the future? As stated earlier, this research was intended to provide exploratory data that may be useful in formulating hypotheses and research questions for the future. Any differences in cardiovascular disease risk between Japanese Natives and Japanese Americans may lead to research that will address the underlying mechanisms involved. It was expected that differences in cardiovascular disease risk would be found, but the extent to which any differences may be explained is limited by the design of the study. However, comparing the lifestyle and environment data gathered from the questionnaire may give some ideas as to why high cardiovascular disease risk 
is present. Also, this could guide future research projects. If the null hypothesis is rejected, this research should be continued to the next step: why does a difference in cardiovascular disease risk exist between the Japanese Native population and the Japanese American population?

This research provides data important in the evaluation of accelerated plethysmography (APG) as a tool for cardiovascular disease risk assessment. It is possible that the APG may demonstrate clinical utility as a risk assessment instrument, alone or in combination with other commonly used instruments.

\section{LIMITATIONS AND ASSUMPTIONS}

The design of this study is quasi-experimental since it resembles a nonequivalentcomparison group design, and therefore will be limited to the extent that inferences may be made. However, the exploratory nature of this research is intended to provide research questions for future investigations rather than conclusions for making inferences. The sampling procedures used limits the scope and generalizability of the results. It is assumed that instruments used to gather data (e.g., questionnaires and risk profiles) were valid and reliable when used with both samples, and that all subjects were truthful in answering questions about their health behaviors/status. It is also important to remember that the APG-index and other measures of health status are estimations of health status. 


\section{CHAPTER II}

\section{REVIEW OF LITERATURE}

No previous research on Japanese American cardiovascular diseases has been

found. Therefore, this study may provide the foundation for future research of cardiovascular disease risk in the Japanese American population and the Japanese Native population. Such research could have beneficial implications for other population subsets as well.

"More than 2,600 Ameircans die each day from cardiovascular diseases; an average of a death every 33 seconds. That's more than 954,000 deaths annually; nearly 42 percent of all deaths every year. Extensive clinical and statistical studies have identifed several factors that increase the risk of cardiovascular disease. Theses risk factors can be grouped into two classifications: 1) major risk factors and 2) contributing risk factors. Major risk factors for cardiovascular disease that cannot be changed are heredity, male sex and increasing age. Heredity: Children of parents with cardiovascular disease are more likely to develop it themselves. Race is a consideration, too. African-Americans have moderate high blood pressure twice as often as whites and severe hypertension three times as often. Consequently, their risk of heart disese is greater. Being male: Men have a greater risk of heart attack than women earlier in life. After menopause, women's death rate from heart disease increase. Increasing age: The vast majority of people who die of heart attack are age 65 or older. Contributing risk factors are those associated with increased risk of cardiovascular disease, and can be changed or are modifiable by lifestyle. Cigarette/Tobacco smoke: Smokers' risk of heart attack is more than twice that of nonsmokers. Smokers who have a heart attack are more likely to die and die suddenly (within an hour) than nonsmokers. High blood cholesterol: Based on large population studies, blood cholesterol levels below $200 \mathrm{mg} / \mathrm{dL}$ in middle-aged adults seem to indicate a relatively low risk of cardiovascular disease. A level of $240 \mathrm{mg} / \mathrm{dL}$ and over approximately doubles the risk. High blood pressure: increases the heart's workload, causing the heart to enlarge and weaken over time. Physical inactivity: Regular aerobic exercise plays a significant role in preventing heart and blood vessel disease. Management of stress: Life would be dull without stress, but excessive amounts of stress over a long time may create health problems. For example, people under stress may start smoking 
or smoke more than they otherwise would" (1997 Heart and Stroke, American Heart Association).

On the other hand, because of the increase in the number of older people in Japan, the frequency of disease and injury has increased. Especially, deaths due to such geriatric diseases as cancer, cerebrovascular disease, and heart disease have accounted for $60 \%$ of all deaths (see Table 1, p. 11 ). Of the three, heart disease is gradually decreasing, while cancer is on the rise as a cause of death: In 1993, deaths due to cancer were 235,707 , heart disease were 180,297 , and cerebrovascular disease were 118,794 , while in 1996 , cancer were 263,022 , cerebrovascular disease were 146,552, and heart disease were 139,206 (Department of Welfare in Japan, 1997).

\section{Comparison of Population Densities}

Table II lists the population densities of several counties in Oregon, New York City, Tokyo, and Saga, Japan. The data show more clearly how many people share per one mile square in each place. Individuals living in Oregon experience the most open space. Saga, Japan, a small, rural city, has a population density four times greater than Portland. In addition, Tokyo, Japan has the highest population density in the world (Famighetti, 1996). Tokyo's population density is 1.8 times the population density of New York City and 31.2 times that of Portland. 


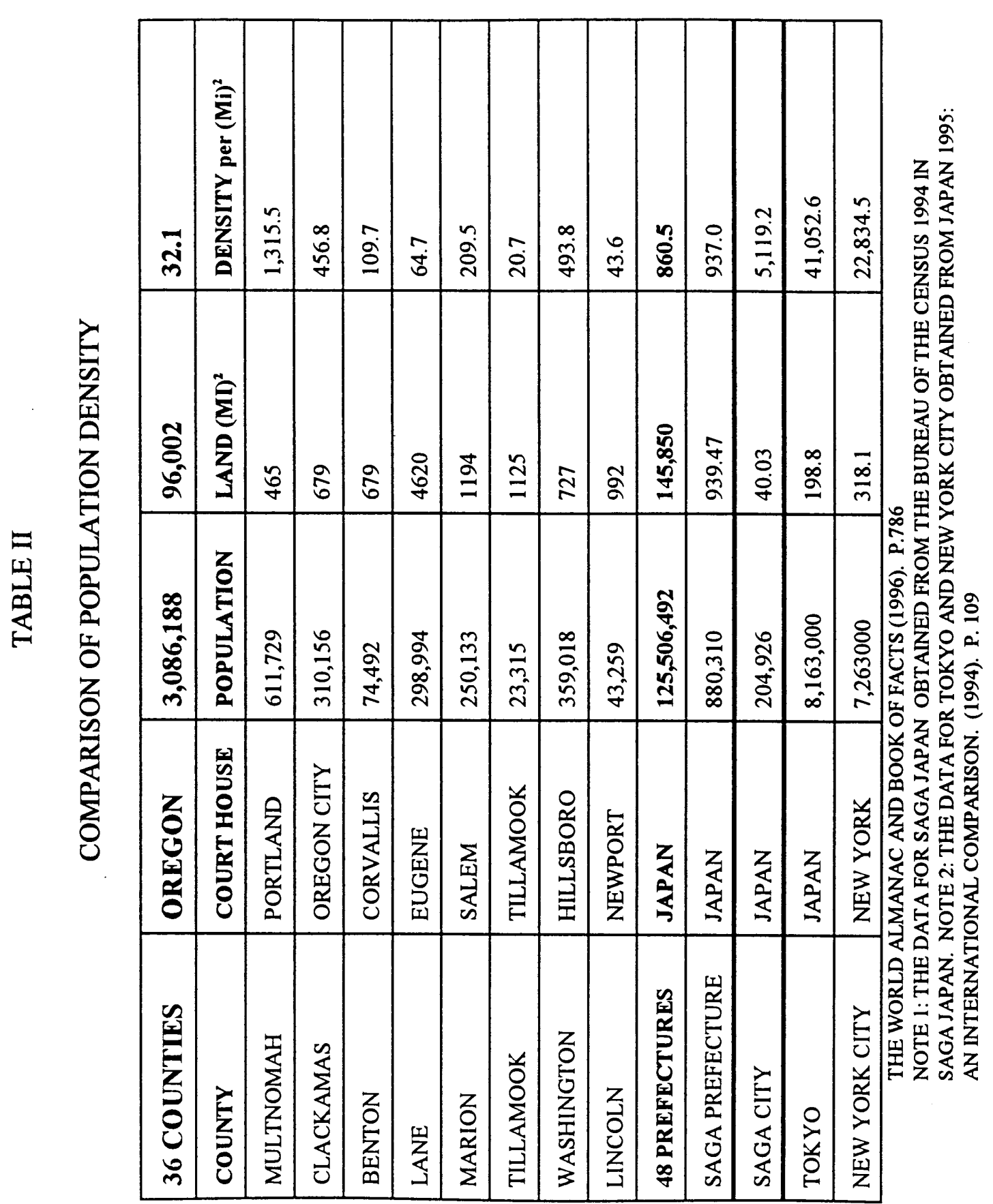


Studying population density is very useful because it gives us the origin and the history of current settlers. Historically, the first immigrants were called "Issei," the second generations were "Nisei," and now most Japanese Americans are "Sansei." The first language of "Nisei" and "Sansei" was English, but most of "Nisei" can speak and write Japanese and are familiar with Japanese culture because most attended Japanese school in the U.S. However, almost all "Sansei" cannot speak or write Japanese. In general, "Sansei" do not perceive this lack of heritage as a loss.

\section{JAPANESE AMERICANS}

It was a little more than one hundred years ago when the first Japanese arrived in Oregon.

"In 1880 there were only three Japanese people in the entire region. Then, it was between 1910 and 1920 that large numbers of Japanese women arrived in Oregon. Under the system of immigration which permitted the bringing of "picture brides," during these ten years the number of women between the ages of 20 and 44 increased from 201 to 769. In 1924, the Immigration Exclusion Act virtually ended immigration until after World War II" (Stearns, 1974).

With increasing Japanese immigration ("Issei"), there was considerable agitation directed toward the Japanese. In a report to the governor on the Japanese situation in Oregon, the Japanese population of Portland in 1920 was estimated at about 1,800 (Stearns, 1974). They earned their living as merchants, lodging house keepers, hotel and eating house owners, tailors, shoemakers, dyers, cleaners, factory workers, and farm hands. 
"In Portland, about 90 per cent of the small hotels and lodging houses were reported to be in the hands of the Japanese, who were gradually extending their operations into various new branches of trade. The Japanese population continued to increase; a survey in 1935 recorded that there were 2,000 firstgeneration Japanese "Issei" and 2,376 second generation Japanese "Nisei" in Oregon, with 273 of the latter over age twenty-one" (Stearns, 1974).

During the early post-World War II years, a small number of Japanese women entered the country as brides of American servicemen who had served in the occupation force (O'Brien \& Fujita, 1991). Immigrations to the U.S. have been increasing every year, and 'there were 8,580 Japanese in Oregon in 1980, which were the largest group immigrants in the total of $2,639,915$ Oregonians. In more detail, there were 740 Japanese in Clackamas County in a total of 243,000 residents, 301 Japanese in Clark County in a total of 192,227 residents, 2,921 Japanese in Multnomah County in a total of 562,300 residents, and 1,094 Japanese in Washington County in a total of 247,800 residents. The highest concentration of the Japanese was in Multonomah County, which includes Portland. The Japanese population was very dispersed, and they did not live in a high degree of concentration. The Japanese tended to be found less conspicuously in a core area of northeast or southeast Portland and, at the same time, they were distributed more prominently in outlying areas. The exclusive and more affluent neighborhoods of southwest Portland, (e.g., the inner West Hills) contained a greater population of Japanese in comparison to other East Asians, such as Chinese and Korean. Vancouver did not have a concentration of people of Japanese descent" (Stearns, 1974).

Unlike the majority of the Chinese and Koreans, the Japanese basically do not want to live in groups. They tend to want to live independently and diligently. In Stearns' report (1974), "The history of the Japanese people in Oregon," he wrote that the Japanese were interested in the purchase of land.

'In the eastern part of Multnomah County the Japanese had established themselves in the farming industry. Beginning in 1906 the Japanese began near Russellville the culture of strawberries. In 1911 almost one-half of the farming lands around Russellville were under their control, their efforts having 
been extended to the raising of all kinds of fruits and vegetables. They had to pay a good price for the rental of the land, usually $\$ 15$ an acre, but they took the best lands so that every acre would be productive. The dairy, hay, grain, and potato industries at this time were not attempted by the Japanese, who found the vegetable and small fruit production so much more profitable on land for which high rentals must be paid. In the Gresham community, where the soil is so well adapted to berry culture and truck gardening, the Japanese had a strong foothold. Fifty percent of the acreage of raspberries, 90 percent of the strawberries, 30 to 40 per cent of the loganberries, and 60 percent of the vegetable gardening were handled by the Japanese, with some inroads being made into the potato and dairying business. The Japanese held the land under lease of three to six years, usually picking the very best land. The majority of those who rent to them are city owners. Some resident farmers rent to them, but many refuse to deal with them feeling that the Japanese crop the ground intensively and rob it of its fertility by the time his lease expires" (Stearns, 1974). 


\section{JAPANESE NATIVES}

There are many elderly Japanese Natives who have worked hard for a long time for Japan. World War II was extremely destructive to Japan, ending on 15 August in 1945 with Japan's defeat. Like any other defeated people, the Japanese were miserable at that time. All of Japan was in disorder. However, the Japanese who survived from World War II desperately worked very hard in order to reconstruct Japan. Because of this generation, in spite of losing many brothers and sisters, enormous amounts of properties, and many old conventions, Japan was reborn, and the Japanese adopted a new Western lifestyle. However, whether it can be shown how the new Western lifestyle has affected Japanese Natives' wellness is still unclear and forms the subject of this research.

\section{DIET}

For hundreds--perhaps thousands--of years, rice, fish, soybean products, and green vegetables made up the traditional Japanese diet. However, after World War II, Western habits penetrated Japanese life to an enormous extent, bringing important and dramatic changes in dietary and eating practices. In particular, consumption of rice as a staple food declined sharply. By contrast, intake of animal foods, such as meat, eggs, milk, and dairy products, has markedly increased. As a result, although diseases associated with undernutrition, such as tuberculosis and other communicable infectious diseases declined after 1947, degenerative diseases of aging are now the leading causes of death (Fujita, 1992). 
New Japanese-type eating habits have been established. This new pattern consists of small servings of boiled rice, with the addition of meat, fish, vegetables, and milk. This eating revolution after World War II (which has included providing school lunches) has been supported by economic growth and may have contributed to the rapid rise in Japanese longevity. In fact, most Japanese before World War II ate only grains and vegetables, and died young.

"In Japan before World War II, while it was not the custom to eat much meat, the custom of taking $3 \mathrm{~g}$ of animal protein per person per day and eating large amounts of rice resulted in a high salt intake" (Matsuzaki, 1992).

Matsuzaki (1992) emphasized that with meat added to the previous Japanese diet, Japanese can expect to live longer, and cautioned that eating fatty meats is a factor in the development of hypercholesterolemia, which leads to ischemic heart disease or myocardial infarction. It has also been reported that Americans eat an average of 320 $\mathrm{g}$ of meat per person per day whereas Japanese eat an average of $100 \mathrm{~g}$ of meat per person per day (Matsuzaki, 1992). Daily meat intake in Japan may represent the ideal quantity to reduce cardiovascular disease. As a result, Matsuzaki (1992) recommended that due to low serum cholesterol levels among Japanese Natives, they should continue the present meat intake. Matsuzaki feels that if Japanese further reduce meat intake, they may increase the risk for cardiovascular disease or weaken bodily resistance against infectious diseases. Therefore, modern Japanese Americans are much more likely to have Matsuzaki's recommended diet, such as a balanced ratio of animal and fish to vegetable protein, retaining rice as the main dish. 


\section{CHAPTER III}

\section{METHODS}

The purpose of this study was to compare the cardiovascular disease risk for Japanese individuals living in the United States with those living in Japan, and to determine whether a significant difference exists. The following methods were used to evaluate cardiovascular disease risk in Japanese Natives and Japanese Americans.

\section{$\underline{\text { Subjects }}$}

The sample of subjects for this research included 134 Japanese Americans and Japanese Natives, forty years of age or older. Japanese American subjects were living in or near Portland, Oregon for at least ten years and Japanese Native subjects were living in or near Saga, Japan. Many of the Japanese Americans were recruited from the Japanese International Baptist Church (JIBC) and "Ikoi-no-kai," one of the Japanese organizations in Portland, Oregon. Methods for recruiting Japanese Natives were similar for each group, and included targeting drug store employees, neighbors, friends, and their relatives. Because of their age, subjects in both samples were surveyed about their current status of health. A questionnaire was used to collect data concerning current medication use, past surgery, diet, exercise, drinking and smoking habits, and family history.

\section{Equipment}

The cardiovascular disease risk of both samples was estimated using the APGindex, the measurement of blood pressure \& resting heart rate, and RISK-O. The 
RISK-O questionnaire assesses the risk of heart disease from the answers to questions in five categories: weight, systolic blood pressure, estimated blood cholesterol level, cigarette smoking, and estrogen use (female only).

The APG is a relatively new device which has been developed in Japan by the Misawa Company (Precaregraph, APG-100; Misawa, Japan). Resembling a laptop computer, it has a keyboard, a monitor, a printer, and a photo-optic sensor located inside a small receptacle into which the tip of a person's index finger is inserted. The photo-optic sensor detects changes in capillary blood flow in the fingertip, and presumably provides information allowing early detection of circulatory insufficiency by measuring blood flow characteristics in the tip of the index finger. An APG-index has been developed which has been hypothesized to indicate a person's cardiovascular disease risk. It is obtained by first calculating the second derivative of the pulse waveform, and identifying "turning points" labelled "a," "b," "c," and "d" (see Figure 1, p. 25).

The APG-index is calculated as follows: $(-b+c+d) / a \times 100$. It is designed to evaluate the peripheral pulse wave of the index finger. A higher APG-index presumably indicates better peripheral circulation while a lower APG-index indicates poorer peripheral circulation. The waveforms obtained can also be classified into seven major patterns (A-G), with " $A$ " indicating good circulation and "B-G" indicating progressively worse circulation (see Figure 2, p. 25). Based on this classification, the APG-index is thought to provide an assessment of health status. 
For example, young, healthy, and active people should expect type "A" or "B" waveforms with a relatively high APG-index. On the other hand, individuals suffering from cerebrovascular diseases or ischemic heart disease, may expect type "D" through "G" waveforms with a lower APG-index. The validity of the APG-index was examined by correlating the APG-index with RISK-O (American Heart Association) scores. Also, blood pressure and resting heart rate were measured with an automatic sphygmomanometer (CITIZEN, Digital Sphygmomanometer / TM-732). 


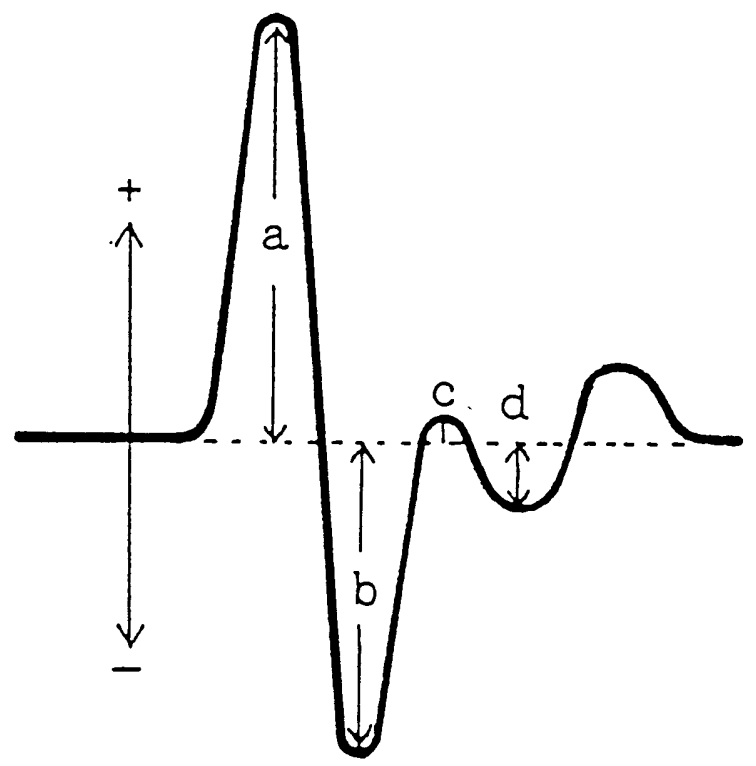

$A P G$ index $=(-b+c+d) / a$

Figure 1. Components (a-e) of accelerated plethysmogram (APG).

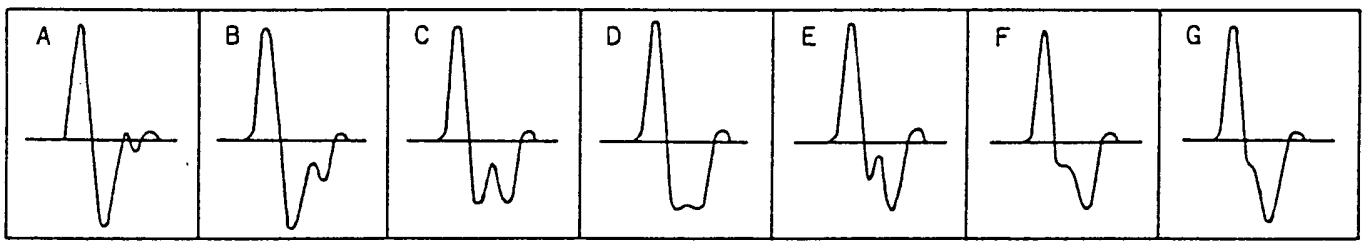

Figure 2. Typical patterns (A-G) of accelerated plethysmogram (APG). 


\section{Procedures}

All subjects signed an informed consent form after receiving an explanation of all procedures. Height and weight were then measured, after which the subject sat in a comfortable chair to complete a health-related questionnaire (Appendix A). Most subjects' body weights were measured with a balance scale with the subjects in light clothing and without shoes. However, several female subjects who exceeded normal weight range or were underweight refused to take the measurement. They stated verbally their weight. However, there were fewer than five individuals in both populations who refused weight measurement. Also, the height measurement was taken with a tape measure.

After that, APG measurements were made, and then blood pressure and resting heart rate were measured with an automatic sphygmomanometer. The subject placed the right index finger into the pulse wave detector, and rested in this position for three minutes. The APG measurements were sometimes repeated for older subjects because of difficulty in obtaining measurable waveforms in some subjects. The average of several pulse waves (3-5) was automatically generated by the accelerated plethysmogram (APG) and used to establish the APG-index. When all of the measurements were completed, the investigator answered any additional questions asked by the subject.

Data collection was begun in October, 1996 and was completed in February, 1997. 


\section{Data Analysis}

Data were analyzed using simple descriptive statistics and correlation according to StatView Student computer program (Feldman \& Gagnon, 1991). Also, contingency tables were used to examine the data with respect to questions about smoking, medication, alcohol consumption, and exercise habits.

The comparison of Japanese Native and Japanese American cardiovascular disease risk was evaluated with t-tests, using a Bonferroni adjustment to protect against an increased Type I error rate (Huck \& Cormier, 1996). An experiment-wise error rate of $p \leq 0.05$ was used. 


\section{CHAPTER IV}

\section{RESULTS}

The following chapter presents the results of the comparison between the cardiovascular disease risk of Japanese Natives living in Saga, Japan and Japanese Americans living in or near Portland. It was hypothesized that differences between Japanese Americans and Japanese Natives would be significant because of cultural differences.

\section{Descriptive Characteristics}

The general characteristics of the Japanese Natives and the Japanese Americans are summarized in Table III.

In Saga, Japan, 67 Japanese Natives were selected in December 1996, while the 67 Japanese American subjects were selected to match the Japanese Natives with respect to age and gender.

Since age and gender were matched in both countries, similar subject characteristics were observed. The exception was that Japanese American males consistently had a higher Body Mass Index (BMI). The recruitment was completed by February 1997. 


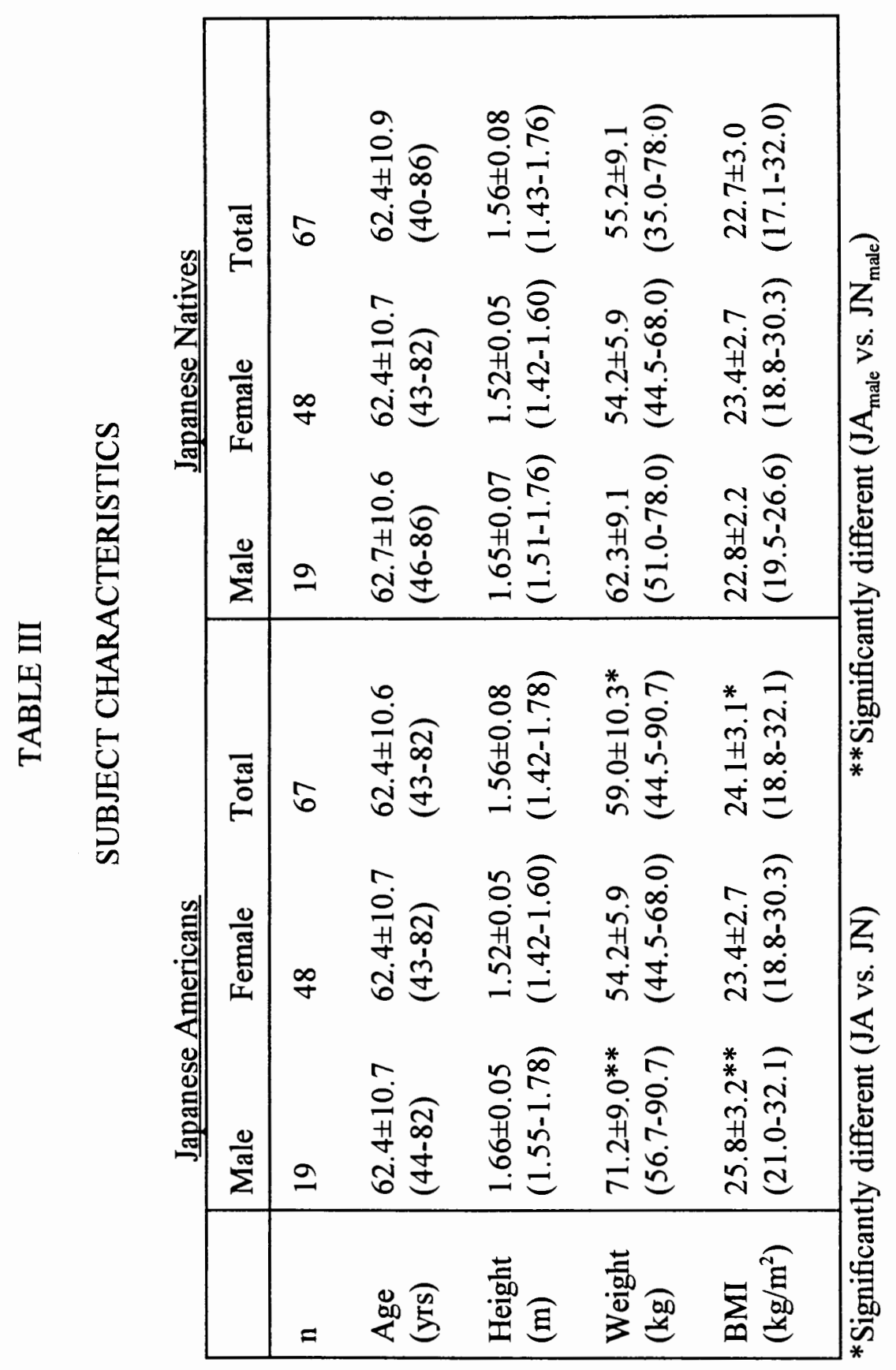




\section{Cardiovascular Disease Risk}

According to the Department of Statistics in the Saga prefecture Health Division (Health and Welfare Statistics Association in Japan, 1996), the causes of death in the Saga prefecture in 1995 were cancer (29\%), cerebrovascular disease (15\%), and cardiovascular disease (14\%). Also, the average life span was 76.1 years for males and 83.0 years for females in 1995. In addition, the Saga prefecture population in 1995 consisted of 419,492 males and 466,020 females, totalling 885,512 .

On the other hand, according to the Oregon State Health Division in Portland (Hall and Johnson, 1997), the causes of death for Chinese and Japanese Americans in Oregon were cancer (28\%), cardiovascular disease $(27 \%)$, and cerebrovascular disease (8.5\%). Also, Chinese and Japanese Americans' life spans in Oregon were 73 years for males and 75 years for females.

Comparing the causes of death in the both populations, the incidence of cardiovascular disease in Japanese Americans was nearly twice that of Japanese Natives. Since the incidence of cardiovascular disease is much higher in Japanese Americans, it was hypothesized this would be reflected in differences related to risk factors. As indicated in Table III and Table IV, there were significant differences in the APG-index, BMI, and weight of the two populations. 


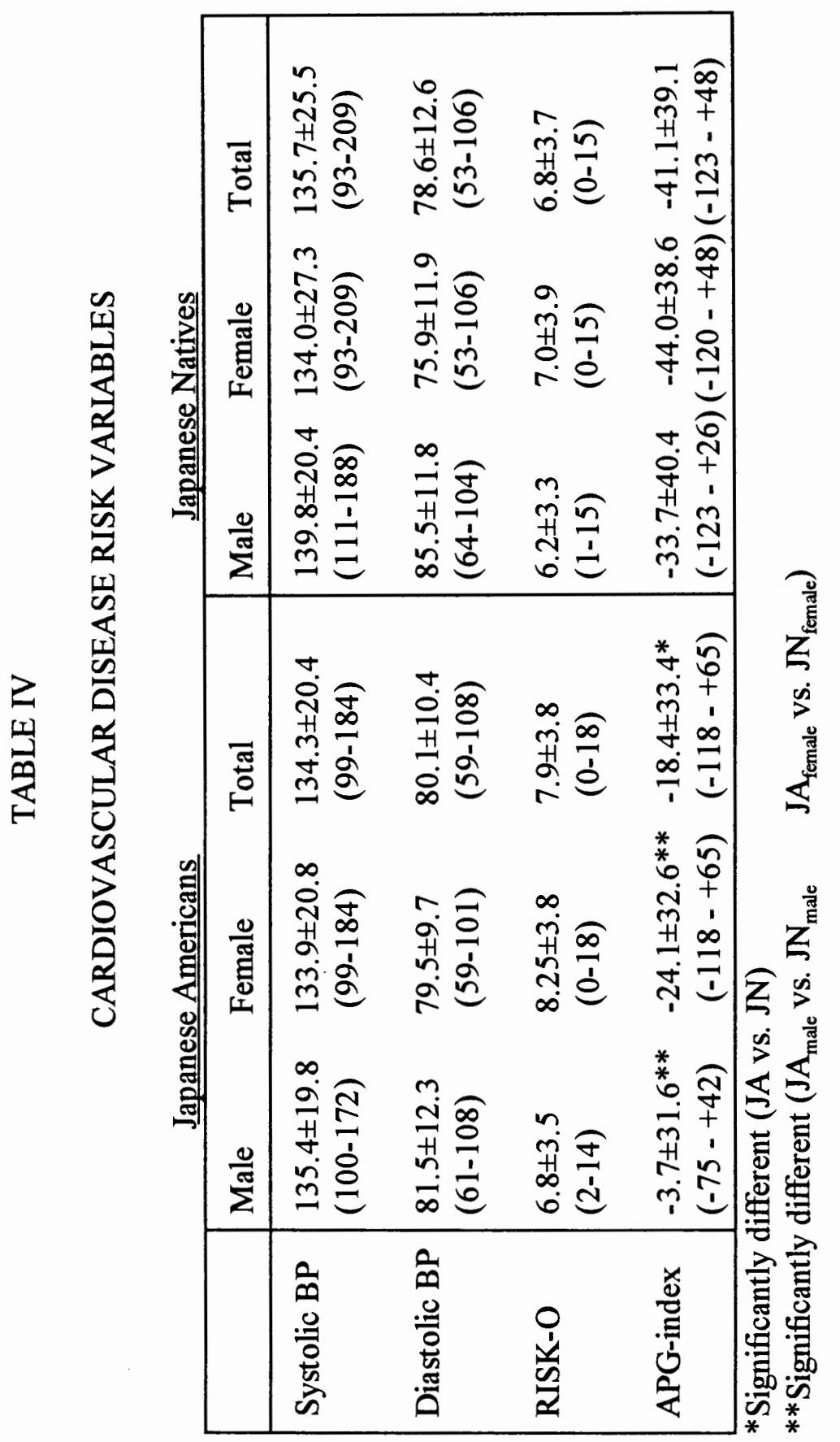


Table V presents the intercorrelation matrix for variables hypothesized to relate to cardiovascular disease risk in Japanese Americans, and Table VI presents a similar matrix for Japanese Natives. The correlation matrixes were evaluated the significance by the table of critical value of correlation coefficient in the level of significance for two-tailed test at $p=.05$. The $p$-value means the smallest significance level at which the null hypothesis can be rejected (Mann, 1992, p. 442). According to the Statistical Tables for Biological, Agricultural and Medical Research, the critical values of correlation coefficients of the degree of freedom (df); 67 subjects in each population, was .25 (Fisher \& Yates, 1963, p. 452).

Table V, Japanese American data, presents each valiable hypothesized to relate to cardiovascular disease risk. Age positively correlated with systolic blood pressure, and negatively correlated with resting heart rate, and APG-index. Systolic blood pressure positively correlated with age, diastolic blood pressure, RISK-0, and BMI, and negatively correlated with APG-index. Diastolic blood pressure positively correlated with diastolic blood pressure, resting heart rate, and RISK-O. Resting heart rate positively correlated with diastolic blood pressure, and negatively correlated with age. APG-index negatively correlated with age and systolic blood pressure. RISK-O positively correlated with BMI, systolic blood pressure and diastolic blood pressure. Weight positvely correlated with BMI.

Table VI, Japanese Native data, presents each variable hypothesized to relate to cardiovascular disease risk. Age positively correlated with systolic blood pressure, 
and negatively correlated with APG-index and weight. Systolic blood pressure positively correlated with age, diastolic blood pressure, and RISK-O. Diastolic blood pressure positively correlated with RISK-O, weight, BMI, and systolic blood pressure. Resting heart rate positively correlated with APG-index. RISK-O positively correlated with BMI, systolic blood pressure, and diastolic blood pressure. Weight positively correlated with BMI and diastolic blood pressure, and negatively correlated with age. BMI positively correlated with diastolic blood pressure, RISK$O$, and weight. 


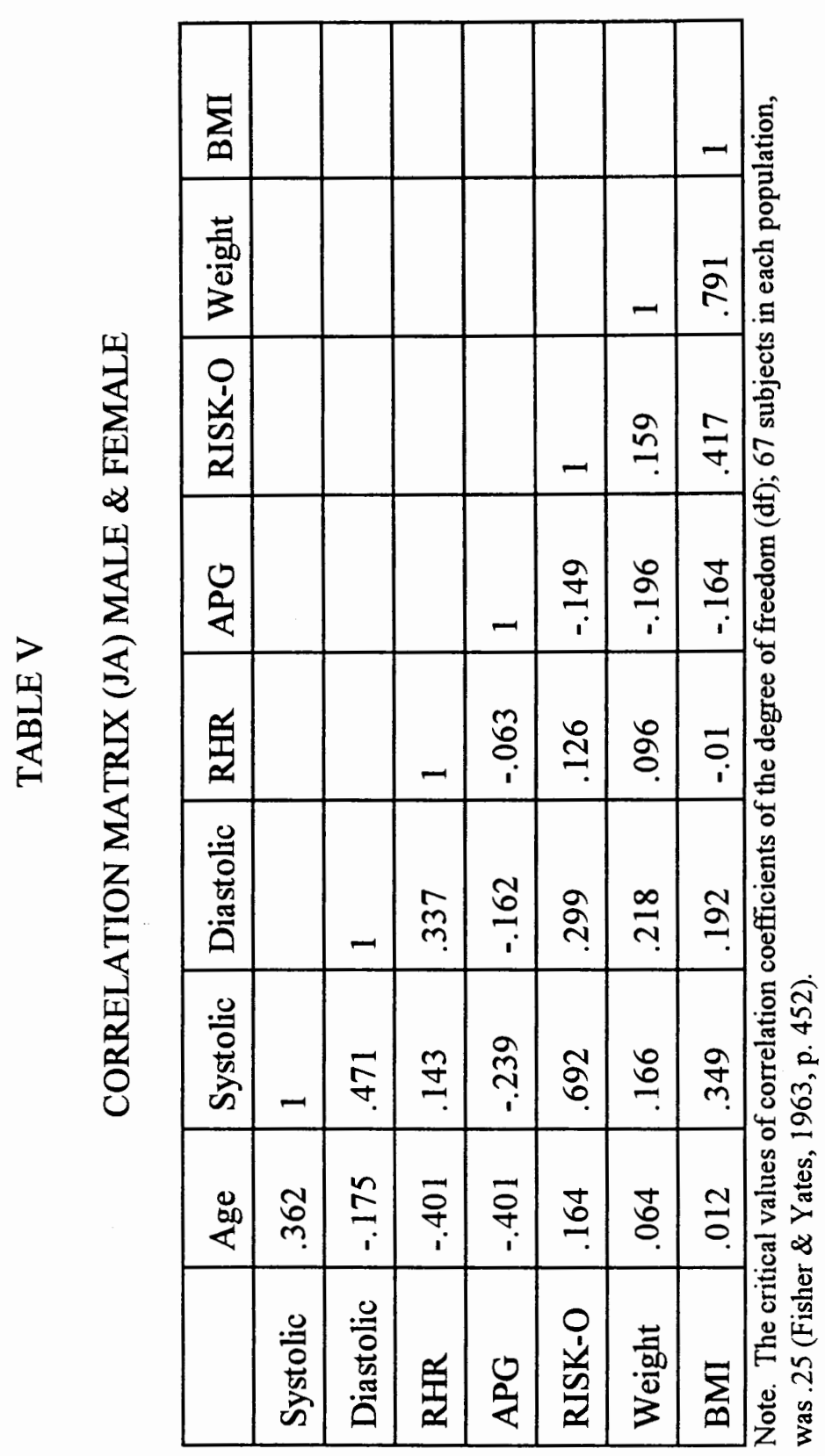




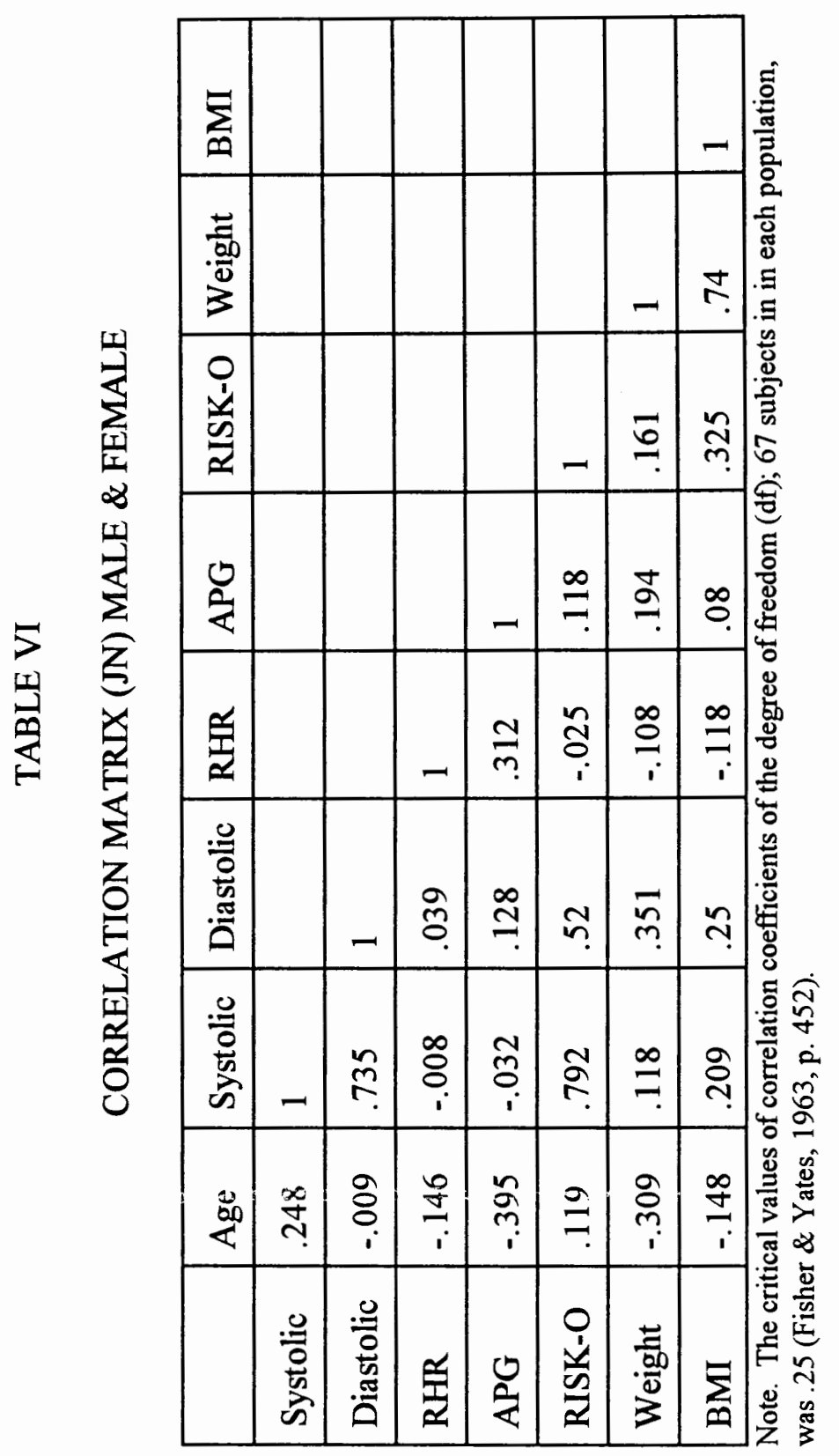




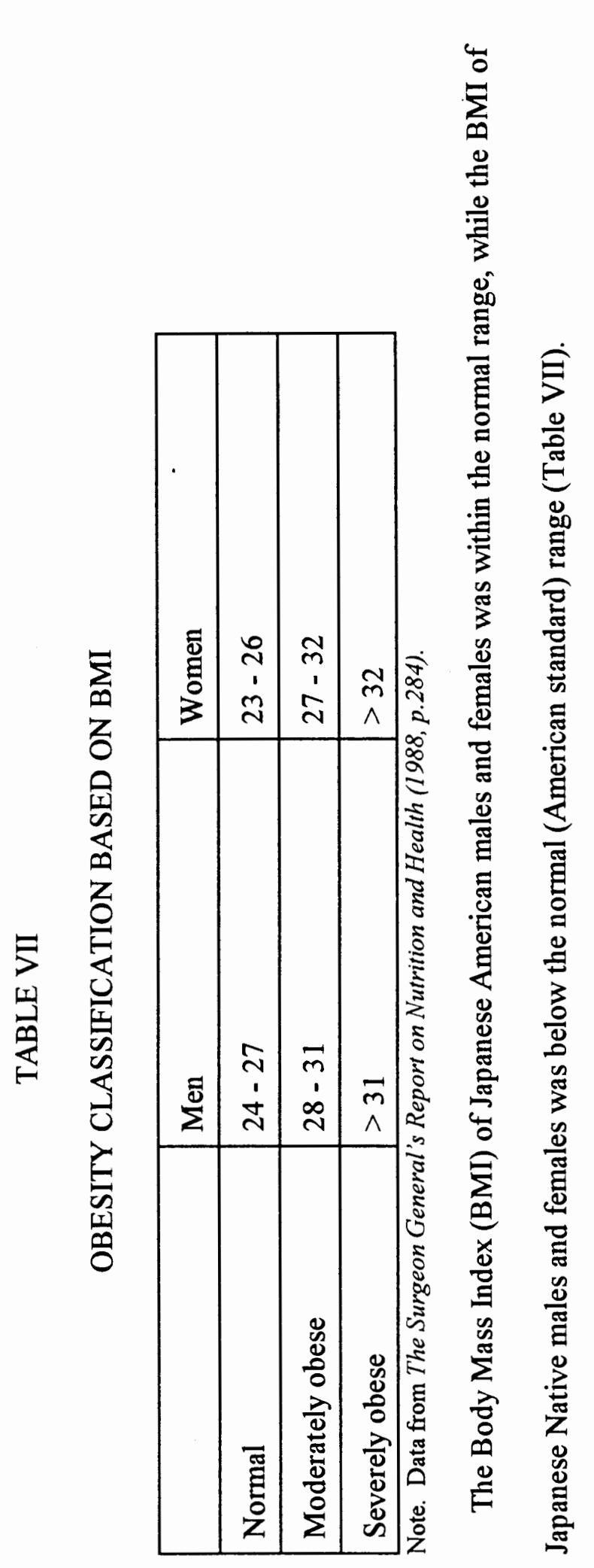



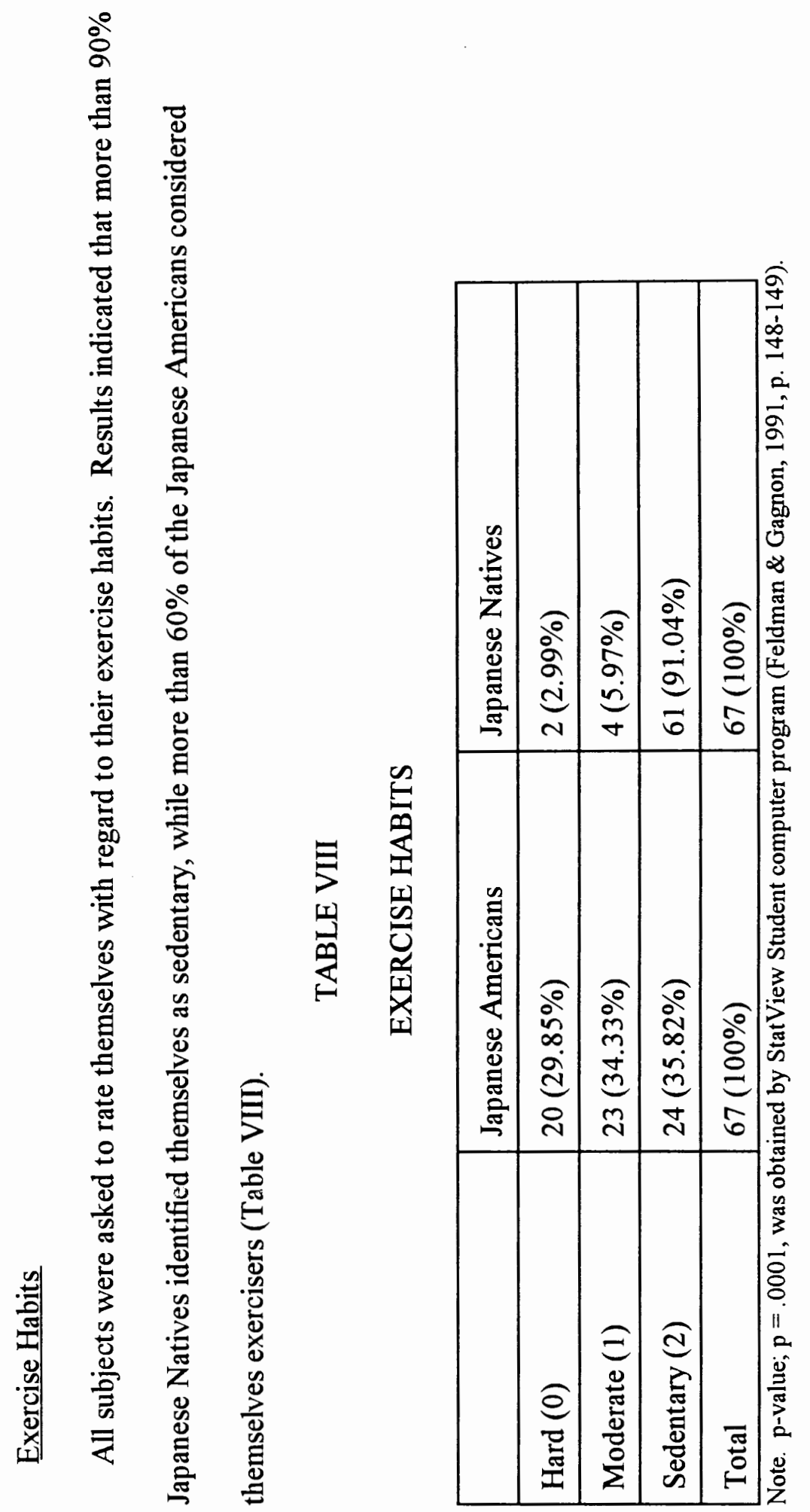
Exercise habits were measured according to the investigator's scale: 0 for frequent exerciser, 1 for moderate exerciser, and 2 for sedentary.

Hard (0) means that the exercise is equivalent to participate in golf, tennis, swimming, or bowling weekly, run, or weight-lifting regularly, or similar equivalent. Moderate (1) means that the exercise is equivalent to walk $20-60 \mathrm{~min}$., 3-5 days per week or similar equivalent. Sedentary (2) means that subjects don't do any kind of exercise. Since the $p$-value; $p=.0001$, was statistically significant, the null hypotesis was rejected for exercise habit. Japanese American had more exercise habit than Japanese Natives.

\section{Medication}

Subjects were also asked about prescription medications they were currently taking. The results indicated that Japanese Natives were using fewer prescription medications than Japanese Americans (Table IX). Medication habits were measured according to the scale: 0 for not currently taking medication, 1 for takes one kind of medication, 2 for takes two kinds of medications, 3 for takes three kinds of medications, 4 for takes four kinds of medications. Since the $p$-value; $p=.0229$, was statistically significant, the null hypothesis was rejected: Japanese Americans were taking more medication than Japanese Natives. 


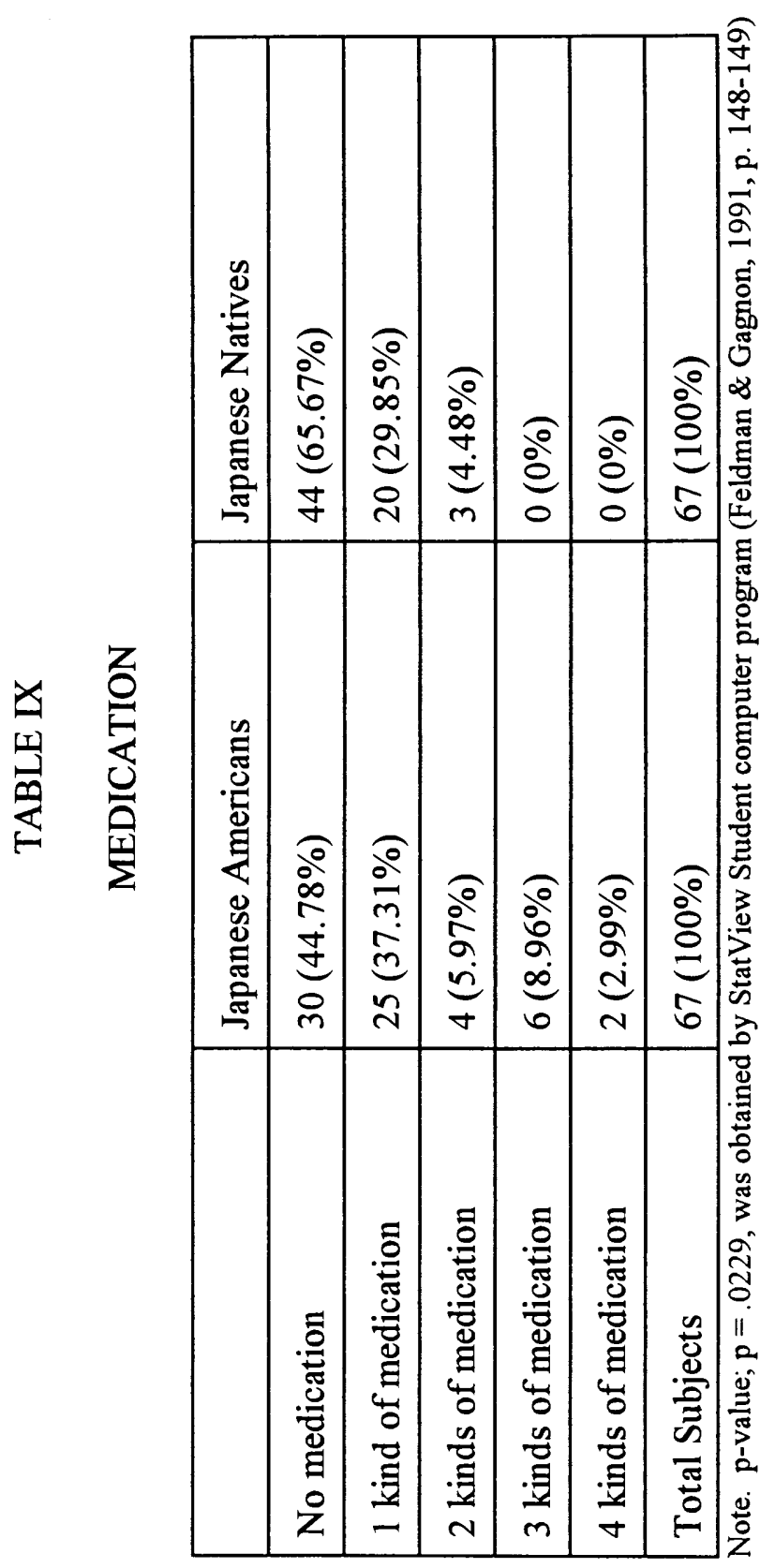




\section{Smoking \& Drinking Habit}

All subjects were asked about their current smoking and drinking habits (Table X and XI). Results indicated that the majority of individuals in both samples were nonsmokers and non-drinkers at the time they were surveyed.

Smoking habits were measured according to the scale: -1 for non-smoking, 0 for former smoker, 1 for moderate smoker, 2 for heavy smoker. Non-smoker means never smoked, former smoker means currently not smoking, moderate smoker means less than half pack per day, and heavy smoker means more than one pack per day. Since the $p$-value, $p=.0595$, was not statistically significant, the null hypothesis was approved: the smoking habits showed similar pattern in the two populations.

Drinking habits were measured according to the scale: -1 for non-drinker, 0 for former drinker, 1 for moderate drinker, 2 for heavy drinker. Non-drinker means currently quit drinking, moderate-drinker means occasional moderate-social drinking, and heavy-drinker means everyday drinks three or more alcohol beverages. Since the $\mathrm{p}$-value, $\mathrm{p}=.0008$, was statistically significant, the null hypothesis was rejected: Japanese Natives have more heavy drinkers than Japanese Americans. 


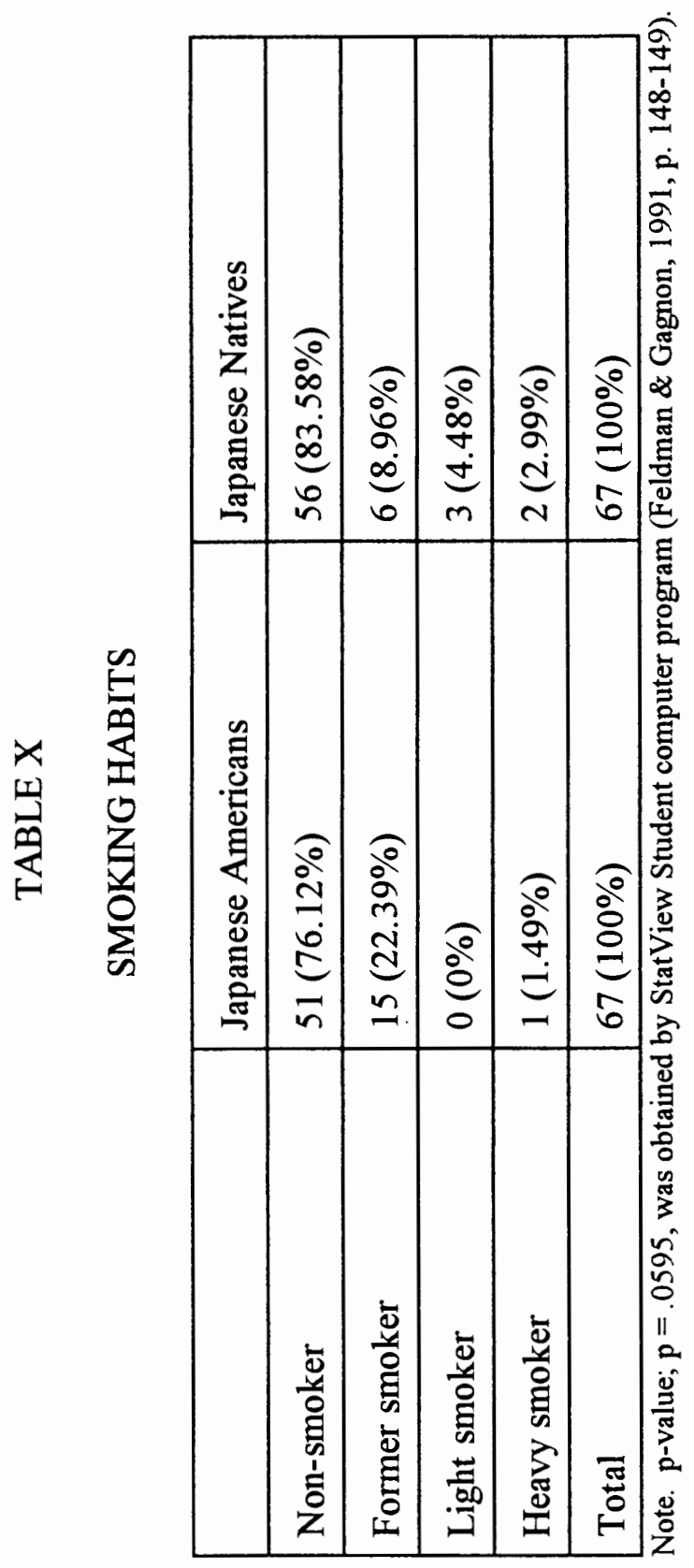




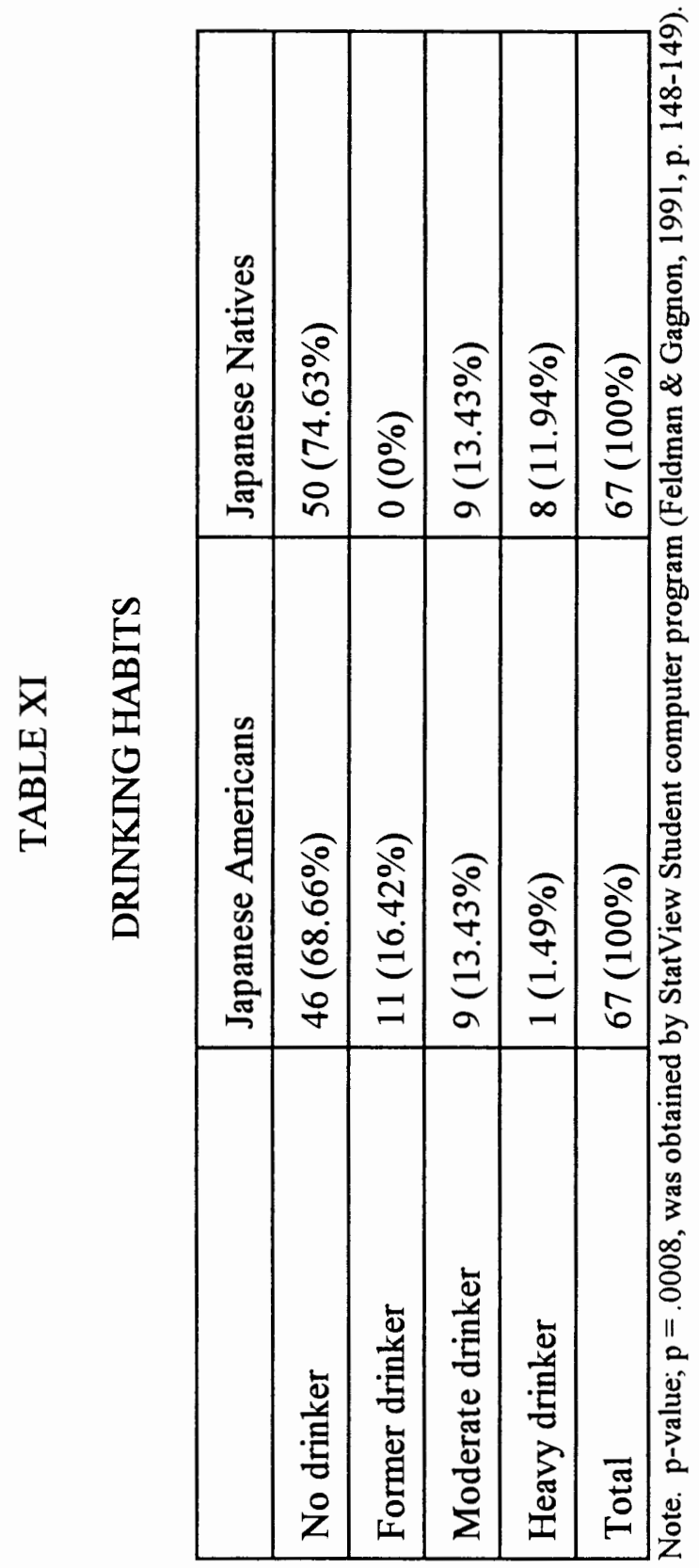




\section{CHAPTER V}

\section{DISCUSSION}

The following chapter presents the discussion of the findings regarding cardiovascular disease risk variables and the APG-index.

\section{Cardiovascular Disease Risk Variables}

The purpose of this study was to examine cardiovascular disease risk (CVR) in Japanese Natives ( $\geq 40 \mathrm{yrs}$ ) living in Saga, Japan and Japanese Americans ( $\geq 40 \mathrm{yrs}$ ) living in or near Portland, Oregon. Accelerated plethysmography, a RISK-O, blood pressure, resting heart rate, and BMI were used to examine CVR. In addition, lifestyle information obtained from a personal history questionnaire was used to assess behaviors related to drinking, smoking, exercise, and medication use. There were statistically significant differences between the samples (e.g., body weight and BMI in males, the APG-index in males and females, the use of medication, and exercise habits), but the data did not provide a clear explanation for the difference in deaths due to cardiovascular disease.

There was a significant difference in the APG-index between Japanese Natives and Japanese Americans, but the APG-index did not correlate highly with any other variable thought to be related to CVR, such as RISK-O, blood pressure, or BMI. The lack of strong correlations between the APG-index and other risk factor variables limits our ability to suggest that the APG-index is somehow predictive of the differences in the major causes of death between Japanese Natives in Saga, Japan 
(cancer, cerebrovascular disease, and heart disease) and Japanese Americans in or near Portland, Oregon (cancer, heart disease, and cerebrovascular disease). Although there was a difference between the mean APG-index of the two samples, the mechanisms underlying this difference remain to be elucidated.

\section{$\underline{\text { APG-index }}$}

It has been demonstrated that endurance training increases the number of capillaries in trained skeletal muscle, thereby allowing a greater capacity for blood flow in the active muscle (Terjung, 1995). Since the APG-index theoretically provides information related to capillary blood flow, and is usually higher in aerobically trained individuals, it may be useful as an indicator of fitness status. Peripheral blood circulation (as measured by the APG-index) may be a factor that can distinguish sedentary from active subjects, because the low exercise levels were associated with a low mean APG-index in Japanese Natives and the high exercise level was associated with a high mean APG-index in Japanese Americans. It appears that elderly Japanese Americans are more active. This could explain, in part, the difference between death rates due to cardiovascular disease. It was also found that Japanese Americans used more prescription medications, and this may have played a role. The design of this study did not allow us to determine which factor (exercise habits or medication use) was more important in explaining differences between the APG-index of Japanese Americans and Japanese Natives. 


\section{Health Care System}

Since medical expenses are very high in the U.S., and not everyone has medical insurance, getting medical treatment may be less convenient for Japanese Americans. On the other hand, Japanese Natives benefit from a national health care system. However, they may focus mostly on their careers so have difficulty finding time on their own to exercise, hoping to substitute a variety of over-the-counter remedies for exercise. Japanese Natives are somewhat reluctant to use prescription medications. Since there are many convenient pharmacies which provide easy access to health care products (many varieties of natural medicines and over-the-counter medications), and there is good medical care insurance for older people in Japan, Japanese Natives enjoy the luxury of many choices for maintaining their health. Especially, since doctors can be reimbursed for treating older people, many Japanese clinics and hospitals are remodeling their facilities to target the older population. According to the chief of medical staff of the Fukuoka Hospital in Saga, Japan, the development of a daycare system for the elderly is a relatively new venture for many Japanese doctors. For example, the hospital can pick up older people who live alone at home, bring them to the hospital, provide them with social interactions, exercise and recreational activities, and a nutritional lunch, and provide transportation home again. The purpose of this system is to decrease long-term medical expenditures in the health care system (Fukuoka, 1997). 


\section{Dietary Habit}

In a comparison of both samples in this study, Japanese Natives ate a smaller amount of food, less meat, more fresh fish, vegetables, and fruits, more salt, less sugar, and less dairy products, while Japanese Americans ate a greater amount and variety of foods. In other words, Japanese Americans ate not only a larger quantity of foods but also a greater variety of foods. They appeared to select foods without cultural discrimination between Japanese food and American food. On a daily basis, Japanese Americans could get a proper amount of meat, fish, vegetables, and daily products more cheaply than Japanese Natives. Therefore, Japanese Americans were able to eat more. For example, one lunch menu at "Ikoi-no-kai" consisted of chicken soup, rice, mashed potatoes, roast beef, boiled broccoli \& carrots, bread, carrot cake or processed fruit. On the other hand, Japanese Natives ate mainly rice and noodles, vegetables and fruits, and less animal protein. As a protein source, fish and soy products are traditional. Historically, Japanese Natives prefer to eat plain rice and side dishes which are usually cooked with soysauce, such as fish and vegetables. The dietary preference for salty, grilled fish has continued for more than 100 years.

During the past decade, the leading cause of death has changed dramatically: tuberculosis, cerebrovascular disease, and pneumonia, were once the leading cause of death in the early 1900's (Department of Welfare, 1996). However, since 1981, deaths from cancer rapidly overcame tuberculosis, cerebrovascular disease, and pneumonia, and became the number one cause of death in Japan (Department of 
Welfare, 1996). Since then, the number of deaths from cancer has never declined is continuing increasing. Although, further study using more sophisticated dietary analysis procedures is needed, the rapid increase of cancer in Japan, may not necessarily to be related to dietary habits, but may be attributable to environmental pollution from industrial development (Koizumi, Aoki, Isukada, Naruse, \& Saitoh, 1994).

\section{$\underline{\text { Lifestyle }}$}

Traditionally, in Japan, older people stay home, and take care of family and run the household. Additionally, medical convenience and high awareness of hygiene have brought longevity for Japanese Natives, even though they eat less food, and expend less energy (i.e., are less active). Although such a lifestyle in Japan happened historically, as a result, Japanese Natives live longer than Japanese Americans. One study (Goto, 1992) mentioned that the once traditional Japanese diet was no longer so typical in Japan, and the incidence of cardiovascular diseases, particularly ischemic heart disease, has increased. However, in this research, people living in Saga prefecture still preferred a traditional diet of rice, salty fish and vegetables. However, it is true that lifestyle and diet in Japan are concurrently becoming Westernized. Therefore, the percentage of adult Japanese Natives who eat less and work out less might decrease in the future. 


\section{CHAPTER VI \\ SUMMARY, CONCLUSION, AND RECOMMENDATIONS}

\section{SUMMARY}

One hundred thirty-four subjects from 40 to 80 years of age were involved in this research in Japan and in Oregon. The research hypothesis was that there is a difference in cardiovascular disease risk of Japanese Natives and Japanese Americans. RISK-O, blood pressure, resting heart rate, and BMI were compared with the APGindex in order to examine the efficacy of using the APG-index to evaluate CVR. Also, questions about medication, drinking, smoking, exercise habit, past surgery, and daily diet were asked using a self-administered questionnaire.

\section{CONCLUSION}

In this research, the mean APG-index was significantly higher in Japanese Americans than in Japanese Natives. However, the hypothesis that the APG-index could be used to evaluate health status regarding cardiovascular disease risk was not supported because of its low correlation with RISK-O and blood pressure. Two of the three primary risk factors in the development and progression of cardiovascular disease: high blood pressure, and smoking behavior were examined. Since many Japanese Native and Japanese American subjects were taking proper medication to control hypertension, there was not a significant difference in the systolic and diastolic blood pressures betweeen the groups. Also, most subjects had quit smoking in both populations; therefore, there were not significant differences in smoking habits 
between populations. If the APG-index had correlated with any one or all of the primary risk factors of cardiovascular disease, this study would have provided preliminary support for the hypothesis that the APG-index can be used to measure CVR. However, since the APG-index did not correlate highly with indicators of CVR, we cannot support the contention that the APG-index can be used to measure CVR. Even if the APG-index cannot be used for the assessment of CVR, the result of this investigation comparing and contrasting the two populations provides some direction for future research concerning the quality of life for both populations.

\section{RECOMMENDATIONS}

Generally speaking, Japan is becoming Westernized. As a group, the Japanese have been following many American ways of life. According to the Center for Population Research \& Census at Portland State University (1997), the Japanese American population in Oregon included 5,309 males and 6,487 females in 1990. Since there was a total of 8,580 Japanese Americans in Oregon in 1980, Japanese immigrations to Oregon have been increasing dramatically in the past decade. The Westernized lifestyle, including early retirement, more food consumption and more exercise, and the increased use of many prescription drugs might improve quality of life, but seems not to lead to longevity. To clarify more details of the factors involved in longevity, a longitudinally designed study on aging may be needed. Lifestyle factors, especially dietary habits and social security for older people in Japan, may be major elements of longevity. 
The causes of cardiovascular disease are complicated, and investigations into cultural differences in CVR may require more time, subjects, and not only quantitative research but also qualitative research methodologies. 


\section{REFERENCES}

Bosch, G., Dawkings, P., \& Michon, F. (1994). Times are changing: Working time in 14 industrialised countries. Geneva, Switzerland: International Labour Organization.

Brown, W. S., Lubove, B. E., \& Kwalwasser. (1994). Karoshi: alternative perspectives of Japanese management styles. Business Horizons, $\underline{37}(2)$, p. 58-61.

Center for Population Research \& Census. Portland OR: Portland State University, 110HH. Telephone: (503) 725-3922

DeMarco, G. (1990). A Short History of Portland. San Francisco: Lexikos.

Department of Statistics. (1995). The Major Cause of Death: Rate \& Prefecture. Saga, Japan: Saga Public Health Office.

Department of Welfare. (1996). The Movement of National Health. Tokyo, Japan: Health and Welfare Statistics Association.

Famighetti, R. (1996). The World Almanac and Book of Facts in 1996. Mahwah, NJ: AK-III Communications Company.

Fisher, R. A. \& Yates, F. (1963). Statistical Tables for Biological, Agricultural and Medical Research. New York: Hafner Publication Company.

Fletcher, G. F., Blair, S. N., Blumenthal, J., Caspersen, C., Chaitman, B., Epstein, S., Falls, H., Froelicher, E. S. S., Froelicher,V.F., \& Pina, I. L. (1992). A Statement for health professionals by the committee on exercise and cardiac rehabilitation of the council on clinical cardiology, American Heart Association. American Heart Association, 86(1), 340-344.

Friedman, E. S. (1993). The Facts of Life in Portland Oregon. Portland, OR: Portland Possibilities, Inc.

Fujita, Y. (1992). Nutritional requirements of the elderly: A Japanese view. Nutrition Reviews, 12 (50), 449-453.

Fukuoka, T \& Fukuoka, H. Fukuoka Hospital. 6-14-10, kaisei Saga, Japan. Telephone: (01181-952-31-4611). 
Gall, S. (1995). The Asian American Almanac: A Reference Work on Asians in the United States. Detroit, MI: Gale Research Inc.

Goto, Y. (1992). Cardiovascular System and Nutrition in the Aging Process. Nutrition Reviews, 12(50), 398-401.

Hall, E., \& Johnson, E. J. (1997). Multicultural Health: Mortality Patterns by Race and Ethnicity, Oregon, 1986-1994. Portland, OR: Oregon Department of Human Resources Health Division, Center for Health Statistics. Telephone: (503) $731-4354$.

Hamajima, N. (1992). "Karoshi" and causal relationships. Japanese Journal of Public Health, $\underline{\text { 39}}(8)$, 445-448.

Hamilton, E. N., Whitney, E. N., \& Sizer, F. S. (1991). Nutrition: Concepts \& Controversies. St. Paul, MN: West Publishing Company.

Hayashi, T., Kobayashi, Y., Yamada, K., \& Yano. (1996). Effect of overtime work on 24-hour ambulatory blood pressure.

Journal of Occupational and Environmental Medicine, 38(10), 1007-1011.

Heart and Stroke Facts: 1996 Statistical supplement. (1996). Dallas, TX: American Heart Association.

Heyward, V. H. (1991). Advanced fitness assessment \& exercise prescription. Champaign, IL: Human Kinetics Books.

Hinrichs, K., Roche, W., \& Sirianni, C. (1991). Working time in transition. Philadelphia, PA: Temple University Press.

Hosokawa, F. (1978). The Sansei: Social Interaction and Ethnic Identification among the Third Generation Japanese. San Francisco, California: R \& E Research Associates, INC.

Iribarren, C., Sharp, D., Burchfiel, C.M., \& Petrovitch, H. (1995). Association of weight loss and weight fluctuation with mortality among Japanese American men. The New England Journal of Medicine, 333(11), 686-692.

Mann, P.S. (1992). Introductory Statistics. New York: John Wiley \& Sons, INC.

Kendis, K. O. (1989). A Matter of Comfort. New York: AMS Press Inc. 
Kobayashi, S. (1992). A scientific basis for the longevity of Japanese in relation to diet and nutrition. Nutrition Reviews, 50(12), 353-354.

Koizumi, A., Aoki, T., Tsukada, M., Naruse, M., \& Saitoh, N. (1994). The Lancet, $\underline{343}(8,910), 1,411-1,412$.

Koyama, H. (1993). Statistics Bureau. Tokyo Japan: The Japan Statistical Association.

Marsella, A. (1993). Counseling and Psychotherapy with Japanese Americans: Cross-Cultural Considerations.

Matsuzaki, T. (1992). Longevity, diet, and nutrition in Japan. Epidemiological Studies, 12(12), 355-359.

Mirkin, B. A. (1987). Early retirement as a labor force policy: an international overview. Monthly Labor Review, 110(3), 19-33.

Morita, M. (1995). Japan 1995: An International Comparison. Tokyo, Japan: Keizai Koho Center (Japan Institute for Social and Economic Affairs).

Morris, J. N. (1994). Exercise in the prevention of coronary heart disease: Today's best buy in public health. Medicine and Science in Sports and Exercise, 26, 807-814.

O’Brien, D. J., \& Fujita, S. S. (1991). The Japanese American Experience. Bloomington and Indianapolis: Indiana University Press.

Physical Activity and Health: A Report of the Surgeon General. Atlanta, GA: U.S. Department of Health and Human Services, Centers for Disease Control and Prevention, National Center for Chronic Disease Prevention and Health Promotion, and The President's Council on Physical Fitness and Sports.

Price, L. W. (1987). Portland's Changing Landscape. Portland OR: Department of Geography, Portland State University.

Sano, Y., Kataoka, Y., Ikuyama, T., \& Osanai, H. (1993). Effect of participation in health-education seminar on blood pressure and accelerated plethysmogram. Chiba Health Education Research, 17, 39-48. 
Sano, Y., Kataoka, Y., \& Osanai, H. (1993). Effects of physical exercise on accelerated plethysmogram (Report 1) - Correlation among pulse rate, blood pressure, and accelerated plethysmogram in the recovery phase after running. Chiba Health Education Research, 16, 39-46.

Sano, Y., Kataoka, Y., \& Osanai, H. (1993). Effects of physical exercise on accelerated plethysmogram (Report 2) - Effects of long-term physical training on accelerated plethysmogram. Chiba Health Education Research, 16, 47-53.

Sano, Y., Kataoka, Y., Ikuyama, T., \& Osanai, H. (1993). Effect of participation in health - education seminar on blood pressure and accelerated plethysmogram. Chiba Health Education Research, 17, 39-48.

Stearns, M. (1974). The History of the Japanese People in Oregon. San Francisco, CA: $R$ and E Research Associate.

Swinbanks, D. (1995). Japan pledges new aid to Minamata victims. Nature, $\underline{375}(6,534), 711$.

Terjung, R.L. (1995). Muscle Adaptation to Aerobic Training. Sports Science Exchange, $\underline{8}, 1-4$.

The Center for Population Research \& Census at Portland State University. (1997). Portland, OR.

Tsugane, S. (1990). Ecological study on cancer mortality and lifestyle in Japan. Japanese Journal of Cancer Clinics, Feb., 425-429.

Uehata, T. (1991). Long working hours and occupational stress - related cardiovascular attacks among middle-aged workers in Japan. Journal of Human Ergology - Tokyo, 20(2), 147-53.

JETRO. U.S. and JAPAN in figures. (1991). Tokyo, Japan: Japan External Trade Organization 
GTIH TVNOSYGd $\mathrm{V}$

V XICNGddV 


\section{A Personal File}

Identification Number:

Examination Date:

Evaluation Date:

Name \& Gender:

Female

Male

Address \& Phone \#: \#

Birthdate:

Age:

Height:

Weight:

1. APG score: higher score is the best.

(Attach the record from a printer on this file.)

2. RISK-O score: Close to zero is the best.

3. Blood Pressure:

4. Resting Heart Rate:

5. Cholesterol: Total

HDL

(Examination Date:

)

Overall comments: 
ヨУIVNNOILSGกठ

g XICNGddV 


\section{QUESTIONNAIRE:}

This study assesses quality of life in adult Japanese people who live in Portland OR and Saga Japan. It has been more than one hundred years since the first Japanese arrived in Oregon. After World War II in 1945, many Japanese people came to the U.S. Now, it's been more than a half century since then. Now, they are called "Japanese

Americans." I would like to assess the living conditions and the quality of life of that generation: Japanese Americans and Japanese natives. Through this research, I want to listen to current health problems, suggest solutions, and encourage them to improve their quality of life.

Please read the questions and answer as completely as you can.

Name:

Today's date:

Gender: Please circle one. Male Female Birthdate:

Age:

Height:

Weight:

Resting Heart Rate: Blood Pressure:

Address:

Phone \#:

Q1. Since when have you been living in the U.S.?

Q2. What is your marital status? Please circle one.

Never married Married Separated Divorced Widowed

If "Married": What is your spouse's nationality?

How long have you been married?

Q3. Are you retired?

If "YES" : How old were you when you retired? 
If "NO": When are you going to retire?

Q4. Do you have a Job?

If "YES": What is it?

If "NO": What was your job before you retired?

Q5. How many days off you have per week?

Q6. How much vacation time do you have in a year?

Q7. In a typical week, how many hours do you work?

Q8. Do you currently exercise regularly?

If "YES": How much do you exercise per week and what do you do?

If "NO": Why don't you exercise?

Q9. What do you eat most? Please provide a sample menu for one day.

Breakfast:

Lunch:

Dinner:

Snacks:

Q10. Do you smoke?

If "YES" : How many cigarettes per day?

If "former smoker" : When did you quit and how many cigarettes did you used to smoke?

When:

How many: 
Q11. Do you drink alcoholic beverages?

If "YES": How much do you drink per week?

If "former drinker" : How much did you used to drink?

Q12. Are you currently taking medication?

If "YES": What kind of medication?

Q13. Do you take vitamin supplements and/or ergogenic remedies?

If "YES": What do you take and how often?

How much do you spend for these things per month?

Q14. Are you currently involved in a church or a buddhist temple or other religious group?

Please circle one. $\underline{\text { CHURCH }}$ BUDDHIST TEMPLE $\underline{\text { OTHER }}$

Q15. Do you own your residence? Please circle one. YES NO

Q16. Do you live in a house or an apartment? Please circle one.

\section{House Apartment}

Q17. Do you know your cholesterol level? YES $\underline{\text { NO }}$

If "YES": When did you get it?

If "NO": Do you want to know it? $\underline{\text { YES }}$ NO

If "YES": Would you be willing to get it checked? YES NO

Q18. Have you ever taken any surgery? If "YES":

When and What

Thank you very much for your participation. 
O-YXSIY

כ XIGNGddV

$6 \varsigma$ 


\section{WHAT YOUR SCORE MEANS}

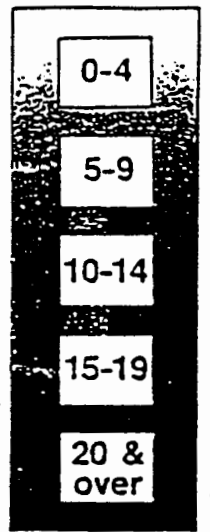

You have one of the lowest risks of Heart Oisease for your age and sex.

You have a low. to moderate risk of Hear Oisease for your age and sex but there is some room for improvernent.

You have a moderate to high risk of Hean Oisease for your age and sex. with considerable room tor improvement on some lactors.

You have a high nisk of developing Hearn Disease for your age and sex with a great deal of room for improvement on all tactors.

You have a very nigh nisk of devetoping Heart Oisease for your age and sex and should take immediate action on all risk factors.

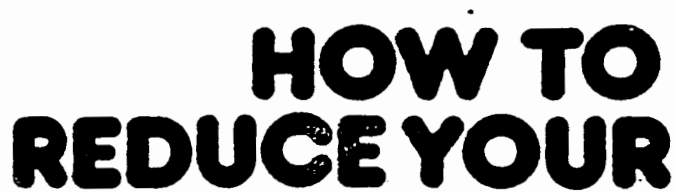

- Try to quit smoking permanently. There are many programs available. - Have your bloco pressure cnecked regularty. preferably every twelve months after age 40 . If your blood pressure is nigh. see your physician. Remember blood pressure medicine is only elfective if taken regularly. - Consicer your naily exercise (or lack of iil. A hat houe of bnst walking. swimming or other enjoyable activity should not be difficult to lit into your day.

- Give some serious thought to your diet. II you are overweignt, or eat a lot of foods hign in saturated las or cholesterd (whole mik, cheese. IgGs. butter, fatty loods. fried loods) then changes should be made in your ciel Look for the American Hear

\section{WARNING}

- Il you have diabetes. gout or a tamily history of near disease. your aciual risk will be greater than indicated by this appraisal.

- If you do noe know your current biood pressure or blood cholesteral level. you should visit your physician or health center to have unem measured. Then figure your score again for a more accurate delermination of your risk.

- If you are overweight, have hign blood pressure or high blood cholesterol, or smoke cigarettes. your longterm risk of heart disease is increased even if your risk in the next several years is low.

\section{RISK}

Association Cookbook at your locat bookstore.

- Visil or write your local Heart Association for furner information and copies of free pamphlets on many related subjects including.

- Recucing your risk of hear artack.

- Controlling high blood pressure.

- Eating to keep your neart healthy.

- How to stop smoking.

- Exercising for good health.

\section{SOME WORDS of CAUTION}

- Il you have diabetes. gout. or a lamily history of hean gisease. your real risk of developing heart disease will be greater than indicated by your AISKO score. If your score is nign and you have one or more of these accilional proolems. you snould give Darticular attention to reducing your risk.

- Il you are a woman under 45 years or a man under 35 years or age. your RISKO score represents an uoper limit on your real risk of developing neart disease. In this case your real risk is probably lower than indicated by your score.

- Il you are a woman whose use of estrogen has coniributed io a nigh AISKO score. you may want 10 consult your onysician. Co not automatically discontinue your prescriplion.

- Using your weignt category 10 estimate your systolic blood pressure or your blood cholesterol level makes your RISKO score less accurate.

- Your score will tenc to overestimate your nsk ir your actual values on inese two important lactors are average tor someone of your heignt and weignt.

- Your score will underestimate your risk il your aciual olood pressure or cholesterol level is above average for someone of your neight or weight. 


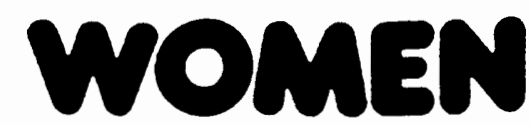

Find the column lor your age group. Everyone starts with a score of 10 points. Work down the page adding points to your score or subtractlng points from your

\section{WEIGHT}

Locate your weight category in the table below. If you are in ...

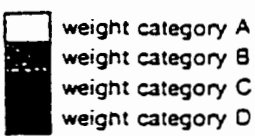

\section{SYSTOLIC BLOOD PRESSURE}

Use the "first" or "higher" number from your most recent blood pressure measurement. II you do not know your blood pressure, estimate it by using the letter for your weight category. If your blood pressure is...
A 119 or less

$i$ between 120 and 139 between 140 and 159 D 160 or greater

\section{BLOOD CHOLESTEROL LEVEL}

Use the number from your most recent blood cho lesterol test. II you do not know your blood choles terol. estimate it by using the letter for your weight caregory. If your blood cholesteral is ...

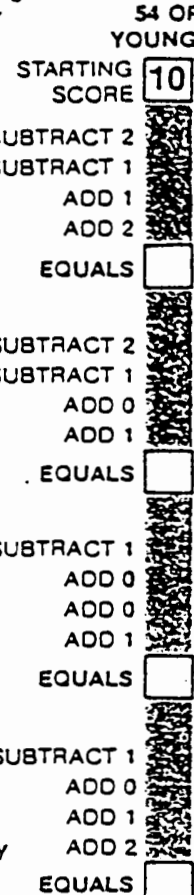

24 OR

55 OR OLDER SCORE 10 SUBTRACT 2 SUBTAACT, AOO 05 $A O O, \therefore$

EQUALS SUETRACT 3 ADO $0-\therefore$ AOO $3 \therefore \therefore$ AOD 6 is EOUALS

SUBTRACT 3 SUBTRACT

$A D O$ $A 003$

EOUALS

SUBTAACT $2 \ddot{\therefore}$ SUBTRACT,

$A D O 1$ AOD 4 EOUALS

\section{ESTROGEN USE}

Birth control pills and hormone drugs contain estrogen. A few examples are: -Premarin 'Ogan -Mensiranol 'Provera 'Evex 'Menest' Estinyl Meurium

\section{do not smoke} smoke less than a
smoke a pack a day smoke more than a pack a day

- Have you ever taken estrogen for five or more years in a row?

- Are you age 35 years or older and are now taking estrogen?

No to borh questions Yes to one or both questions 


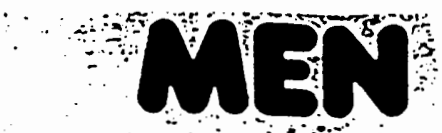

Find the column for your age group Everyone starts with a score of 10 points. Work down the page adding points to your score or subtracting points from your

\section{WEIGHT}

Locate your weight category in the table below. If you are in
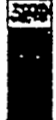
weight category $B$ weight cateçory $\mathrm{C}$ weight category 0

\section{SYSTOLIC BLOOD PRESSURE \\ Use the "first" or -higner" number from your most recent olood pressure measurement. II you do not know your blood pressure. estimate it oy using the letter for your weight category. If your blood pressure is

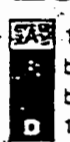 \\ 119 or less between 120 and 139 between 140 and 159 D 160 or.greater}

\section{BLOOD CHOLESTEROL LEVEL}

Use the number irom your most recent blood cholesterol test. II you do not know your olood choles. terol, estimate it oy using the letter for your weight category. If your biood cholesterol is ...

配 199 or less

\section{between 200 and 224}

between 225 and 249

D 250 or higher

\section{CIGARETTE SMOKING} If you ..

(II you smoke a pipe. but not cigarettes. use the same score adiusiment as those cigarette smokers who smoke less than a pack a day.)

Sonot smoke

smoke less than a pack a day -smoke a pack a cay smoke-more than a pack a day

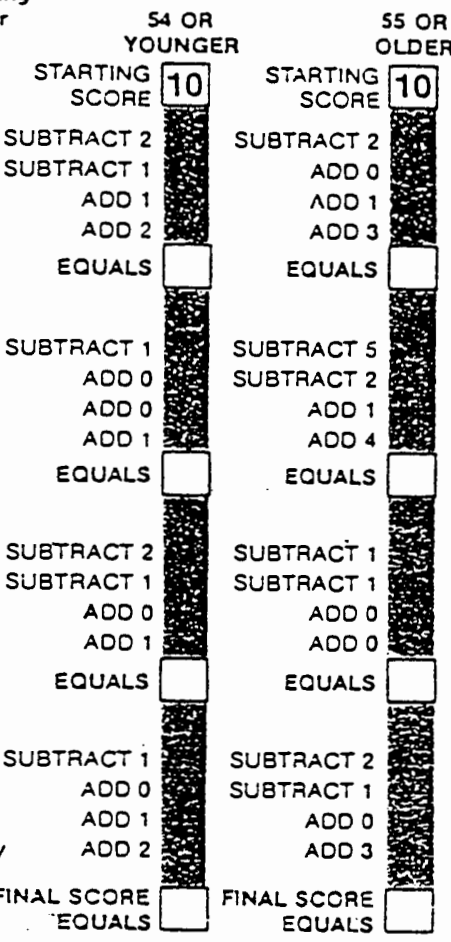

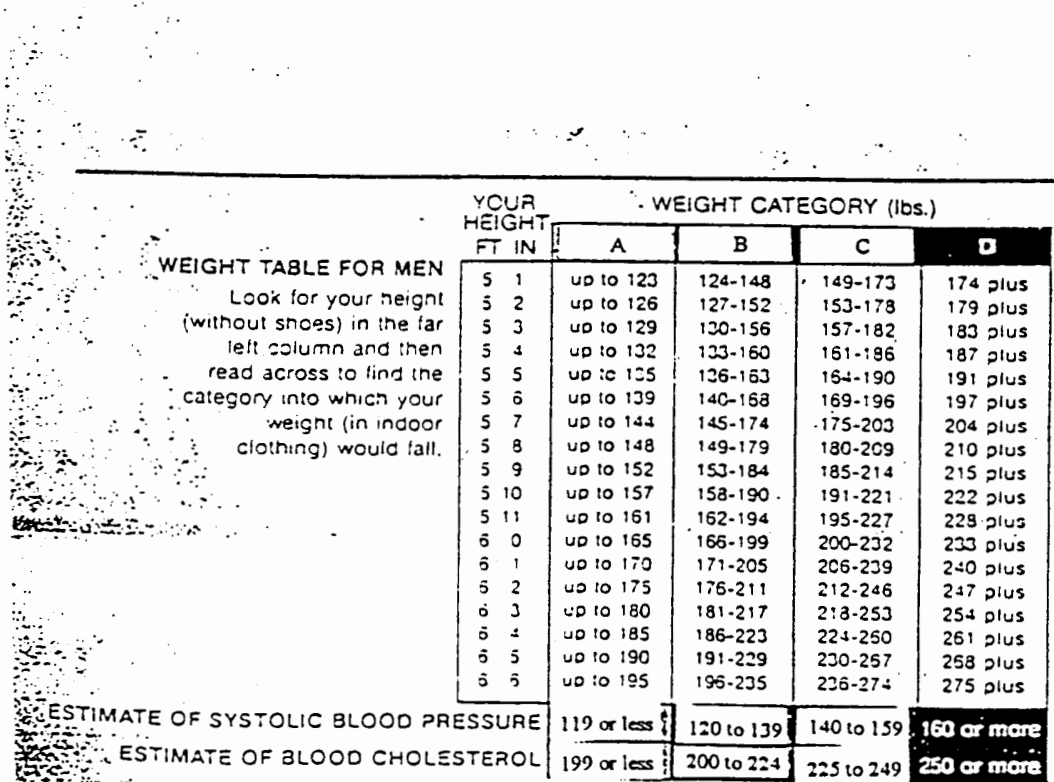

Because coin blood pressure and blood cholesterol are relater: to weignt. an esimate of these nik factors for each weignt category is prinied at ine jortom of the taole. 